\section{Pacific Northwest}

National Laboratory

Operated by Battelle for the

U.S. Department of Energy

\title{
Third Quarter Seismic Report for Fiscal Year 2007
}

Pacific Northwest National Laboratory

Hanford Seismic Assessment Team
A. C. Rohay
M. D. Sweeney
D. C. Hartshorn
R. E. Clayton
J. L. Devary

September 2007

Prepared for the U.S. Department of Energy under Contract DE-AC05-76RL01830 


\title{
DISCLAIMER
}

This report was prepared as an account of work sponsored by an agency of the United States Government. Neither the United States Government nor any agency thereof, nor Battelle Memorial Institute, nor any of their employees, makes any warranty, express or implied, or assumes any legal liability or responsibility for the accuracy, completeness, or usefulness of any information, apparatus, product, or process disclosed, or represents that its use would not infringe privately owned rights. Reference herein to any specific commercial product, process, or service by trade name, trademark, manufacturer, or otherwise does not necessarily constitute or imply its endorsement, recommendation, or favoring by the United States Government or any agency thereof, or Battelle Memorial Institute. The views and opinions of authors expressed herein do not necessarily state or reflect those of the United States Government or any agency thereof.

\author{
PACIFIC NORTHWEST NATIONAL LABORATORY \\ operated by \\ BATTELLE \\ for the \\ UNITED STATES DEPARTMENT OF ENERGY \\ under Contract DE-AC05-76RL01830 \\ Printed in the United States of America \\ Available to DOE and DOE contractors from the \\ Office of Scientific and Technical Information, \\ P.O. Box 62, Oak Ridge, TN 37831-0062; \\ ph: (865) 576-8401 \\ fax: (865) 576-5728 \\ email: reports@adonis.osti.gov

\footnotetext{
Available to the public from the National Technical Information Service, U.S. Department of Commerce, 5285 Port Royal Rd., Springfield, VA 22161 ph: (800) 553-6847 fax: (703) 605-6900

email: orders@ntis.fedworld.gov

online ordering: http://www.ntis.gov/ordering.htm
} 


\title{
Third Quarter Seismic Report for Fiscal Year 2007
}

\author{
A. C. Rohay \\ M. D. Sweeney \\ D. C. Hartshorn \\ R. E. Clayton \\ J. L. Devary
}

September 2007

Prepared for

the U.S. Department of Energy

under Contract DE-AC05-76RL01830

Pacific Northwest National Laboratory

Richland, Washington 99352 


\section{Summary}

The Hanford Seismic Assessment Program (HSAP) provides an uninterrupted collection of highquality raw and processed seismic data from the Hanford Seismic Network for the U.S. Department of Energy and its contractors. The Hanford Seismic Assessment Team locates and identifies sources of seismic activity and monitors changes in the historical pattern of seismic activity at the Hanford Site. The data are compiled, archived, and published for use by the Hanford Site for waste management, Natural Phenomena Hazards assessments, and engineering design and construction. In addition, the seismic monitoring organization works with the Hanford Site Emergency Services Organization to provide assistance in the event of a significant earthquake on the Hanford Site. The Hanford Seismic Network and the Eastern Washington Regional Network consist of 41 individual sensor sites and 15 radio relay sites maintained by the Hanford Seismic Assessment Team.

For the Hanford Seismic Network, 16 local earthquakes were recorded during the third quarter of fiscal year 2007. The largest event (magnitude 2.0) occurred on April 16, 2007 and was located $4 \mathrm{~km}$ southwest of the 400 Area in the Columbia River basalts at a depth of approximately $3 \mathrm{~km}$. Stratigraphically, 7 earthquakes occurred in the Columbia River basalts (approximately 0-4 km depth), 1 earthquake in the pre-basalt sediments (approximately $5-8 \mathrm{~km}$ depth), and 8 earthquakes in the crystalline basement (approximately 9-25 km depth). Geographically, 8 earthquakes occurred in swarm areas, and 8 earthquakes were classified as random events.

The Hanford strong motion accelerometer (SMA) network was triggered on the 300 Area and the 400 Area SMA by the $2.0 \mathrm{M}_{\mathrm{c}}$ seismic event that occurred on April 16, 2007. The maximum vertical acceleration was $0.07 \% \mathrm{~g}$ and the maximum horizontal acceleration was $0.05 \% \mathrm{~g}$ at the 300 Area SMA, $13.5 \mathrm{~km}$ from the event. At the 400 Area SMA, only $5.2 \mathrm{~km}$ from the event, the maximum vertical acceleration was $0.25 \% \mathrm{~g}$ and the maximum horizontal acceleration was $0.23 \% \mathrm{~g}$. These are the first recordings of a small local earthquake on the SMA network. The reportable action level of $2 \% \mathrm{~g}$ for Hanford facilities is approximately 8 times larger than the peak accelerations observed at the 400 Area and no action was required. 


\section{Acronyms}

\begin{tabular}{|c|c|}
\hline BWIP & Basalt Waste Isolation Project \\
\hline CRBG & Columbia River Basalt Group \\
\hline DOE & U.S. Department of Energy \\
\hline ETNA & strong motion accelerometer manufactured by Kinemetrics \\
\hline EWRN & Eastern Washington Regional Network \\
\hline FY & fiscal year \\
\hline GPRS & General Packet Radio Service \\
\hline GPS & Global Positioning System \\
\hline HSAP & Hanford Seismic Assessment Program \\
\hline HSN & Hanford Seismic Network \\
\hline IRIS & Incorporated Research Institutions for Seismology \\
\hline LIGO & Laser Interferometric Gravitational-Wave Observatory \\
\hline $\mathrm{M}_{\mathrm{c}}$ & coda-length magnitude \\
\hline $\mathrm{M}_{\mathrm{L}}$ & local magnitude \\
\hline PNNL & Pacific Northwest National Laboratory \\
\hline SMA & strong motion accelerometer \\
\hline USGS & United States Geological Survey \\
\hline UTC & Universal Time, Coordinated \\
\hline UW & University of Washington \\
\hline WHC & Westinghouse Hanford Company \\
\hline
\end{tabular}





\section{Contents}

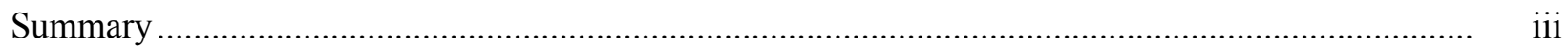

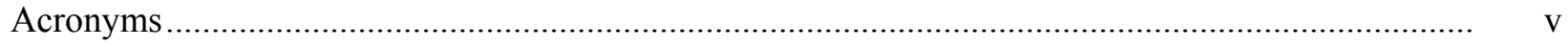

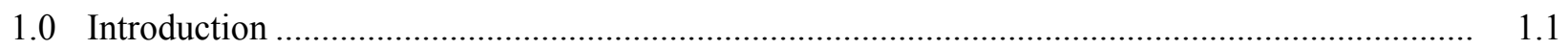

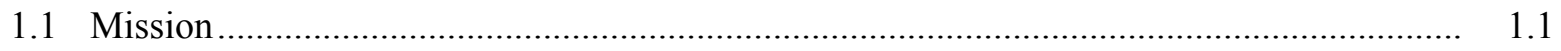

1.2 History of Monitoring Seismic Activity at Hanford …................................................. 1.1

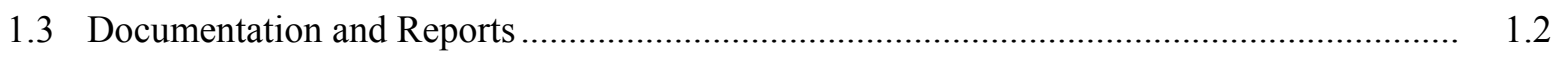

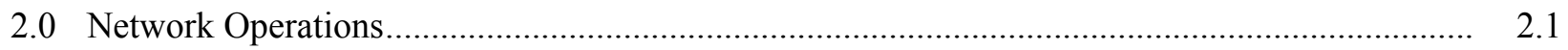

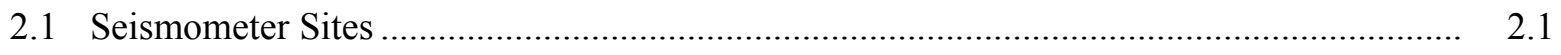

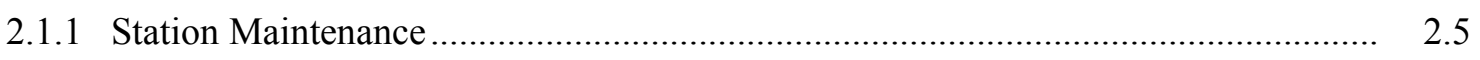

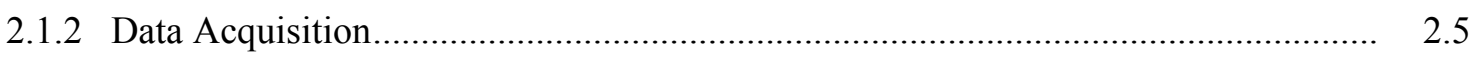

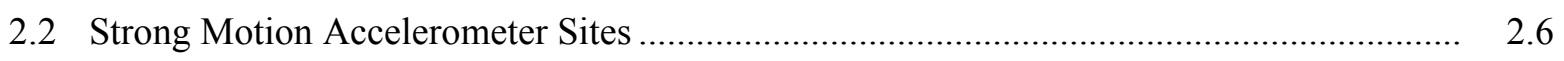

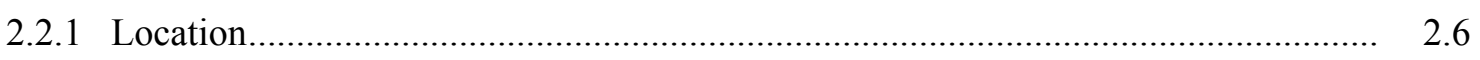

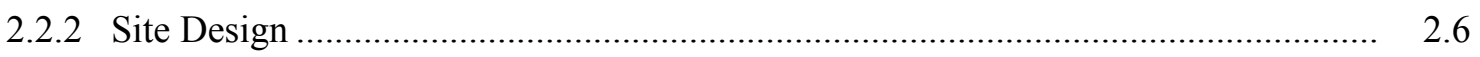

2.2.3 Strong Motion Accelerometer Operations Center ............................................... 2.8

2.2.4 Strong Motion Operational Characteristics ....................................................... 2.8

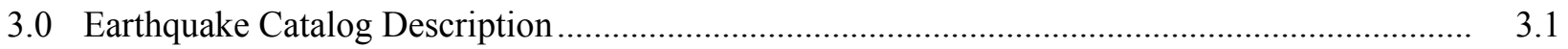

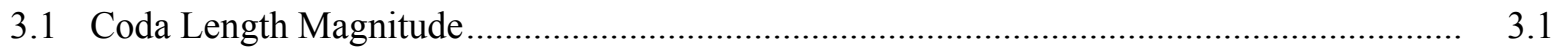

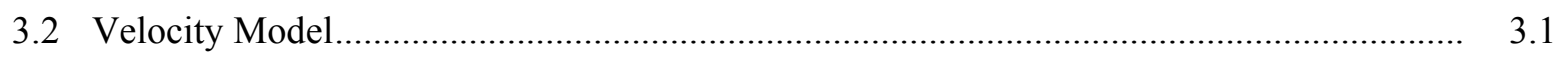

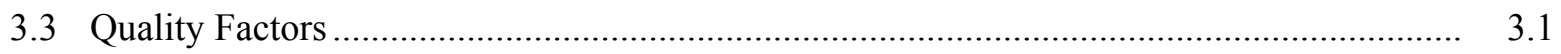

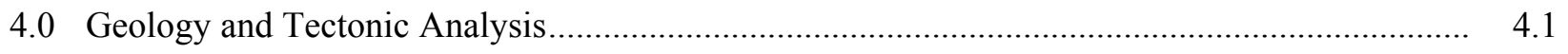

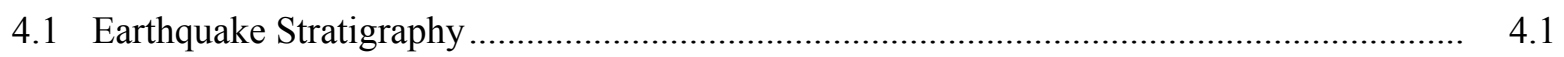

4.2 Geologic Structure Beneath the Monitored Area ............................................................ 4.1

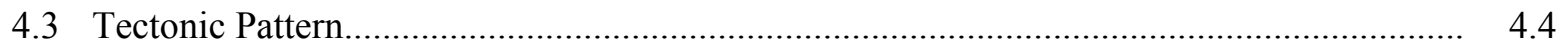

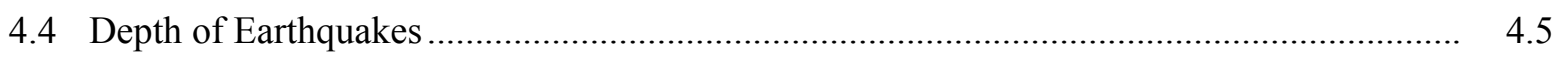

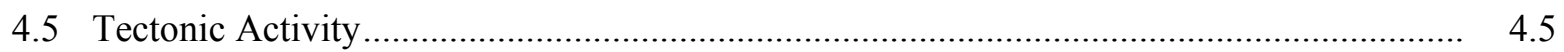

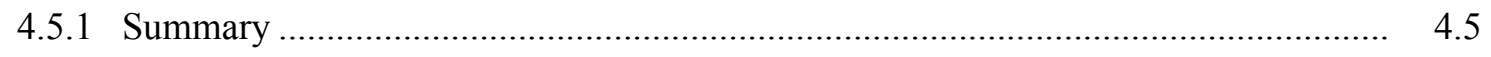

4.5.2 Third Quarter Earthquakes of FY 2007 .......................................................... 4.7

5.0 Strong Motion Accelerometer Operations ........................................................................ 5.1

5.1 FY 2007 Triggers of the Hanford SMA Network ........................................................... 5.1

6.0 Capabilities in the Event of a Significant Earthquake .......................................................... 6.1

6.1 Use of the SMA Network in the Event of an Earthquake ................................................. 6.1

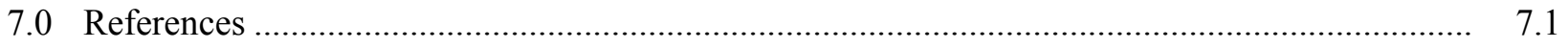




\section{Figures}

2.1 Locations of Seismograph Stations and Strong Motion Accelerometer Sites in the Hanford Seismic Network

2.2 Locations of Seismograph Stations in the Eastern Washington Regional Network

2.3 Schematic Diagram of a Strong Motion Accelerometer Installation.......................................... 2.8

4.1 Tectonic Map of Columbia Basin Showing Major Seismic Source Structures ........................... 4.2

4.2 Geologic Cross Sections Through the Columbia Basin .......................................................... 4.3

4.3 Location of all Earthquakes Occurring in the Hanford Monitoring Area Between

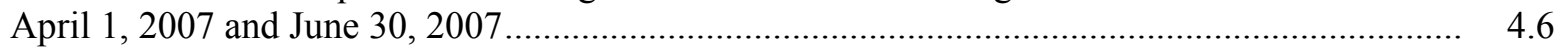

5.1 April 16, 2007 Microearthquake Acceleration Time Histories at 300 Area SMA ..................... 5.2

5.2 April 16, 2007 Microearthquake Acceleration Time Histories at 400 Area SMA ..................... 5.3

\section{Tables}

2.1 Seismic Stations in the Hanford Seismic Network ...............................................................

2.2 Seismic Stations in the Eastern Washington Regional Network .................................................... 2.3

2.3 Free-Field Strong Motion Accelerometer Sites .................................................................... 2.6

2.4 Instrument Parameters for the Kinemetrics ETNA ${ }^{\text {TM }}$ System in the Hanford SMA Network ...... $\quad 2.7$

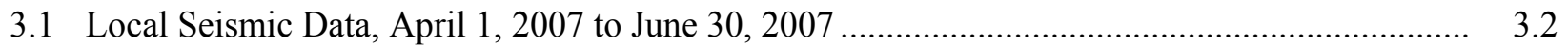

3.2 Seismic Velocities for Columbia Basin Stratigraphy .............................................................. 3.4

4.1 Thicknesses of Stratigraphic Units in the Monitoring Area .................................................... 4.4

4.2 Number of Local Earthquakes Occurring in Stratigraphic Units ............................................. 4.5

4.3 Summary of Earthquake Locations for FY 2007 …............................................................. 4.7 


\subsection{Introduction}

This report covers the locations of seismicity within the Hanford monitoring region of south-central Washington for the third quarter of fiscal year (FY) 2007 and provides the geologic interpretations of those earthquakes.

\subsection{Mission}

The principal mission of the Hanford Seismic Assessment Program (HSAP) at the Hanford Site is to maintain the seismometer and strong motion accelerometer (SMA) sites, report data from measured events, and provide assistance in the event of an earthquake. This mission supports the U.S. Department of Energy (DOE) and the other Hanford contractors compliance with DOE Order 420.1B, Chapter IV, Section 3.d "Seismic Detection" and DOE Order G 420.1-1, Section 4.7, "Emergency Preparedness and Emergency Communications." DOE Order 420.1B requires facilities or sites with hazardous materials to maintain instrumentation or other means to detect and record the occurrence and severity of the seismic event. The HSAP maintains the seismic network located on and around the Hanford Site. The data collected from the seismic network can be used to support facility or site operations to protect the public, workers, and the environment from the impact of seismic events.

In addition, HSAP provides an uninterrupted collection of high-quality raw seismic data from the Hanford Seismic Network (HSN) located on and around the Hanford Site, and the Eastern Washington Regional Network (EWRN). This report provides interpretations of seismic events from the Hanford Site and vicinity. Hanford Seismic Assessment locates and identifies sources of seismic activity, monitors changes in the historical pattern of seismic activity at the Hanford Site, and builds a "local" earthquake database (processed data) that is permanently archived. The focus of this report is the precise location of earthquakes proximal to or on the Hanford Site, specifically between 46 degrees and 47 degrees north latitude and between 119 degrees and 120 degrees west longitude. Data from the EWRN and other seismic networks in the northwest provide the Seismic Assessment Project with necessary regional input for the seismic hazards analysis at the Hanford Site. These seismic data are used to support Hanford Site contractors for waste management activities, Natural Phenomena Hazards assessments, and engineering design and construction.

\subsection{History of Monitoring Seismic Activity at Hanford}

Assessing seismic activity at the Hanford Site was initiated in 1969 by the United States Geological Survey (USGS) under a contract with the U.S. Atomic Energy Commission. In 1975, the University of Washington (UW) assumed responsibility for the network and subsequently expanded it. In 1979, the Basalt Waste Isolation Project (BWIP) became responsible for collecting seismic data for the Hanford Site as part of site characterization activities. Rockwell Hanford Operations, followed by Westinghouse Hanford Company (WHC), operated the local network and were the contract technical advisors for the EWRN operated and maintained by UW. Funding ended for BWIP in December 1988. Assessment of seismic activity and responsibility for the UW contract were then transferred to WHC's Environmental Division. Maintenance responsibilities for the EWRN also were assigned to WHC who made major upgrades to EWRN sites. 
Effective October 1, 1996, all seismic assessment activities were transferred to the Pacific Northwest National Laboratory (PNNL). ${ }^{1}$

The Hanford SMA network was constructed during 1997 and came on-line in May 1997. It operated until September 30, 1997, when it was mothballed due to lack of funding. Funding was restored on October 1, 1998, by joint agreement between the DOE and PNNL. Operation of the SMA sites resumed on November 20, 1998, and has operated continuously since that time.

\subsection{Documentation and Reports}

The HSAP issues quarterly reports of local activity, an annual catalog of earthquake activity on and near the Hanford Site, and special-interest bulletins on local seismic events. The HSAP also provides information and special reports to other functions as requested. Earthquake information provided in these reports is subject to revisions if new data become available. In addition, an archive of all seismic data from the HSN is maintained by PNNL.

\footnotetext{
${ }^{1}$ Pacific Northwest National Laboratory is operated by Battelle Memorial Institute for the U.S. Department of Energy.
} 


\subsection{Network Operations}

\subsection{Seismometer Sites}

The seismic network consists of two designs of equipment and sites: seismometer sites and SMA sites. Seismometer sites are designed to locate earthquakes and determine their magnitude and hypocenter location. SMA sites are designed to measure ground motion and will be discussed in Section 2.2.

The HSN and the EWRN consist of 41 sensor sites. Most sites are in remote locations and require solar panels and batteries for power. The HSN uses 23 sites (Table 2.1 and Figure 2.1) and the EWRN uses 36 sites (Table 2.2 and Figure 2.2). Eighteen sites are shared by both networks. The networks have 45 combined data channels because Gable Butte and Frenchman Hills East are three-component sites, each consisting of one vertical, one north-south horizontal, and one east-west horizontal data channel. Both networks use 15 additional telemetry relay sites. Data from all sites or relays are transmitted to the Sigma V building, Richland, Washington.

Table 2.1. Seismic Stations in the Hanford Seismic Network

\begin{tabular}{|c|c|c|c|c|}
\hline Station & $\begin{array}{c}\text { Latitude } \\
\text { Deg. Min. N }\end{array}$ & $\begin{array}{c}\text { Longitude } \\
\text { Deg. Min. W }\end{array}$ & Elevation (m) & Station Name \\
\hline BEN & $46 \mathrm{~N} 31.13$ & $119 \mathrm{~W} 43.02$ & 340 & Benson Ranch \\
\hline BLT & $45 \mathrm{~N} 54.91$ & $120 \mathrm{~W} 10.55$ & 659 & Bicklelton \\
\hline BRV & $46 \mathrm{~N} 29.12$ & 119W59.47 & 920 & Black Rock Valley \\
\hline BVW & $46 \mathrm{~N} 48.66$ & 119W52.99 & 670 & Beverly \\
\hline $\mathrm{CRF}$ & $46 \mathrm{~N} 49.50$ & 119W23.22 & 189 & Corfu \\
\hline ET3 & $46 \mathrm{~N} 34.64$ & 118W56.25 & 286 & Eltopia Three \\
\hline *FHE & $46 \mathrm{~N} 57.11$ & $119 \mathrm{~W} 29.82$ & 455 & Frenchman Hills East \\
\hline$* \mathrm{GBB}$ & $46 \mathrm{~N} 36.49$ & $119 \mathrm{~W} 37.62$ & 177 & Gable Butte \\
\hline GBL & $46 \mathrm{~N} 35.92$ & $119 \mathrm{~W} 27.58$ & 330 & Gable Mountain \\
\hline $\mathrm{H} 2 \mathrm{O}$ & $46 \mathrm{~N} 23.75$ & $119 \mathrm{~W} 25.38$ & 158 & Water \\
\hline LOC & $46 \mathrm{~N} 43.02$ & $119 \mathrm{~W} 25.85$ & 210 & Locke Island \\
\hline MDW & $46 \mathrm{~N} 36.79$ & $119 \mathrm{~W} 45.66$ & 330 & Midway \\
\hline MJ2 & $46 \mathrm{~N} 33.45$ & 119W21.54 & 146 & May Junction Two \\
\hline OT3 & $46 \mathrm{~N} 40.14$ & $119 \mathrm{~W} 13.98$ & 322 & Othello Three \\
\hline PRO & $46 \mathrm{~N} 12.73$ & $119 \mathrm{~W} 41.15$ & 550 & Prosser \\
\hline RED & $46 \mathrm{~N} 17.92$ & $119 \mathrm{~W} 26.30$ & 366 & Red Mountain \\
\hline RSW & $46 \mathrm{~N} 23.67$ & $119 \mathrm{~W} 35.48$ & 1,045 & Rattlesnake Mountain \\
\hline SNI & $46 \mathrm{~N} 27.85$ & $119 \mathrm{~W} 39.60$ & 312 & Snively Ranch \\
\hline VT2 & $46 \mathrm{~N} 58.04$ & 119W58.95 & 1,270 & Vantage Two \\
\hline WA2 & $46 \mathrm{~N} 45.32$ & 119 W33.94 & 244 & Wahluke Slope \\
\hline WIW & $46 \mathrm{~N} 25.76$ & $119 \mathrm{~W} 17.26$ & 128 & Wooded Island \\
\hline WRD & $46 \mathrm{~N} 58.20$ & 119W08.69 & 375 & Warden \\
\hline YPT & $46 \mathrm{~N} 02.93$ & 118W57.73 & 325 & Yellepit \\
\hline
\end{tabular}




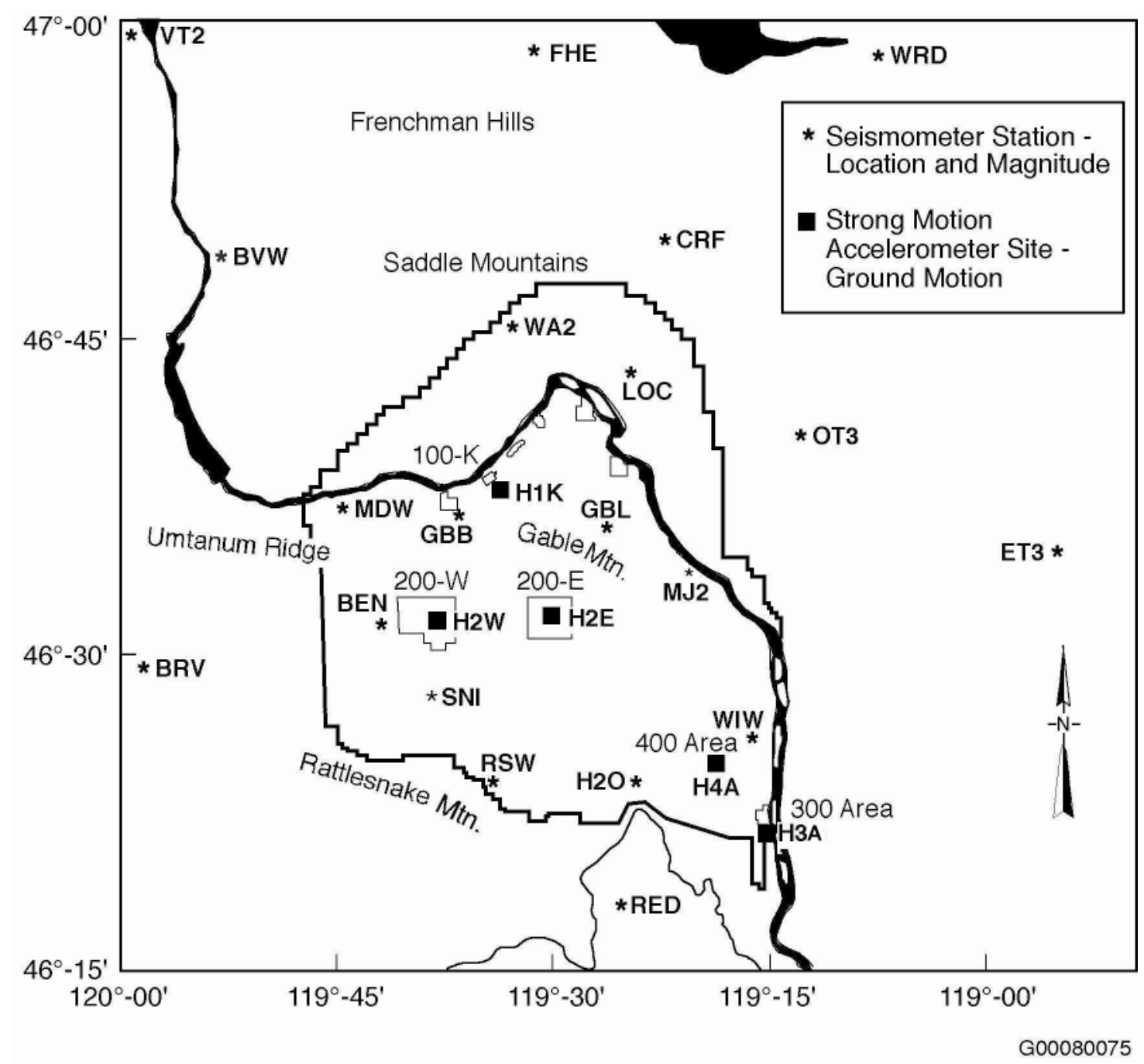

Figure 2.1. Locations of Seismograph Stations and Strong Motion Accelerometer Sites in the Hanford Seismic Network. (See Tables 2.1 and 2.3 for description of locations.) Bickelton (BLT), Prosser (PRO), and Yellepit (YPT) are shown on Figure 2.2. 
Table 2.2. Seismic Stations in the Eastern Washington Regional Network

\begin{tabular}{|c|c|c|c|c|}
\hline \multicolumn{5}{|c|}{$\begin{array}{l}\text { The first column is the three-letter seismic station designator. The latitude and longitude, elevation above sea level } \\
\text { in meters, and the full station name follow this. The locations of the stations are all in Washington unless other- } \\
\text { wise indicated; locations were determined from a Global Positioning System (GPS). }\end{array}$} \\
\hline Station & $\begin{array}{c}\text { Latitude } \\
\text { Deg. Min. N. }\end{array}$ & $\begin{array}{c}\text { Longitude } \\
\text { Deg. Min. W. }\end{array}$ & Elevation (m) & Station Name \\
\hline BLT & $45 \mathrm{~N} 54.91$ & $120 \mathrm{~W} 10.55$ & 659 & Bickleton \\
\hline BRV & $46 \mathrm{~N} 29.12$ & 119W59.47 & 920 & Black Rock Valley \\
\hline BVW & $46 \mathrm{~N} 48.66$ & 119W52.99 & 670 & Beverly \\
\hline CBS & $47 \mathrm{~N} 48.26$ & 120W02.50 & 1,067 & Chelan Butte South \\
\hline CRF & $46 \mathrm{~N} 49.50$ & $119 \mathrm{~W} 23.22$ & 189 & Corfu \\
\hline DPW & $47 \mathrm{~N} 52.25$ & $118 \mathrm{~W} 12.17$ & 892 & Davenport \\
\hline DY2 & $47 N 59.11$ & $119 \mathrm{~W} 46.28$ & 890 & Dyer Hill Two \\
\hline ELL & $46 \mathrm{~N} 54.58$ & 120W33.98 & 789 & Ellensburg \\
\hline EPH & $47 \mathrm{~N} 21.38$ & $119 \mathrm{~W} 35.76$ & 661 & Ephrata \\
\hline ET3 & $46 \mathrm{~N} 34.64$ & $118 \mathrm{~W} 56.25$ & 286 & Eltopia Three \\
\hline ETW & $47 \mathrm{~N} 36.26$ & 120W19.94 & 1,477 & Entiat \\
\hline *FHE & $46 \mathrm{~N} 57.11$ & $119 \mathrm{~W} 29.82$ & 455 & Frenchman Hills East \\
\hline GBL & $46 \mathrm{~N} 35.92$ & 119W27.58 & 330 & Gable Mountain \\
\hline LNO & $45 \mathrm{~N} 52.31$ & $118 \mathrm{~W} 17.11$ & 771 & Lincton Mountain Oregon \\
\hline LOC & $46 \mathrm{~N} 43.02$ & $119 \mathrm{~W} 25.85$ & 210 & Locke Island \\
\hline MDW & $46 \mathrm{~N} 36.79$ & $119 \mathrm{~W} 45.66$ & 330 & Midway \\
\hline MJ2 & $46 \mathrm{~N} 33.45$ & 119W21.54 & 146 & May Junction Two \\
\hline MOX & $46 \mathrm{~N} 34.64$ & $120 \mathrm{~W} 17.89$ & 501 & Moxee City \\
\hline NAC & $46 \mathrm{~N} 43.99$ & 120W49.42 & 728 & Naches \\
\hline NEL & $48 \mathrm{~N} 04.21$ & 120W20.41 & 1,500 & Nelson Butte \\
\hline OD2 & $47 \mathrm{~N} 23.26$ & 118W42.58 & 553 & Odessa Two \\
\hline OT3 & $46 \mathrm{~N} 40.14$ & 119W13.98 & 322 & Othello Three \\
\hline PAT2 & $45 \mathrm{~N} 53.03$ & $119 \mathrm{~W} 45.40$ & 259 & Paterson Two \\
\hline PRO & $46 \mathrm{~N} 12.73$ & 119W41.15 & 550 & Prosser \\
\hline RSW & $46 \mathrm{~N} 23.67$ & 119W35.48 & 1,045 & Rattlesnake Mountain \\
\hline SAW & $47 \mathrm{~N} 42.10$ & $119 \mathrm{~W} 24.03$ & 701 & St. Andrews \\
\hline TBM & $47 \mathrm{~N} 10.20$ & 120W35.88 & 1,006 & Table Mountain \\
\hline TRW & $46 \mathrm{~N} 17.32$ & 120W32.31 & 723 & Toppenish Ridge \\
\hline TWW & $47 \mathrm{~N} 08.29$ & 120W52.10 & 1,027 & Teanaway \\
\hline VT2 & $46 \mathrm{~N} 58.04$ & 119W58.95 & 1,270 & Vantage Two \\
\hline WA2 & $46 \mathrm{~N} 45.32$ & 119W33.94 & 244 & Wahluke Slope Two \\
\hline WAT & $47 \mathrm{~N} 41.92$ & 119W57.24 & 821 & Waterville \\
\hline WIW & $46 \mathrm{~N} 25.76$ & $119 \mathrm{~W} 17.26$ & 128 & Wooded Island \\
\hline WRD & $46 \mathrm{~N} 58.20$ & 119W08.69 & 375 & Warden \\
\hline YA2 & $46 \mathrm{~N} 31.60$ & 120W31.80 & 652 & Yakima Two \\
\hline YPT & 46N02.93 & 118W57.73 & 325 & Yellepit \\
\hline
\end{tabular}




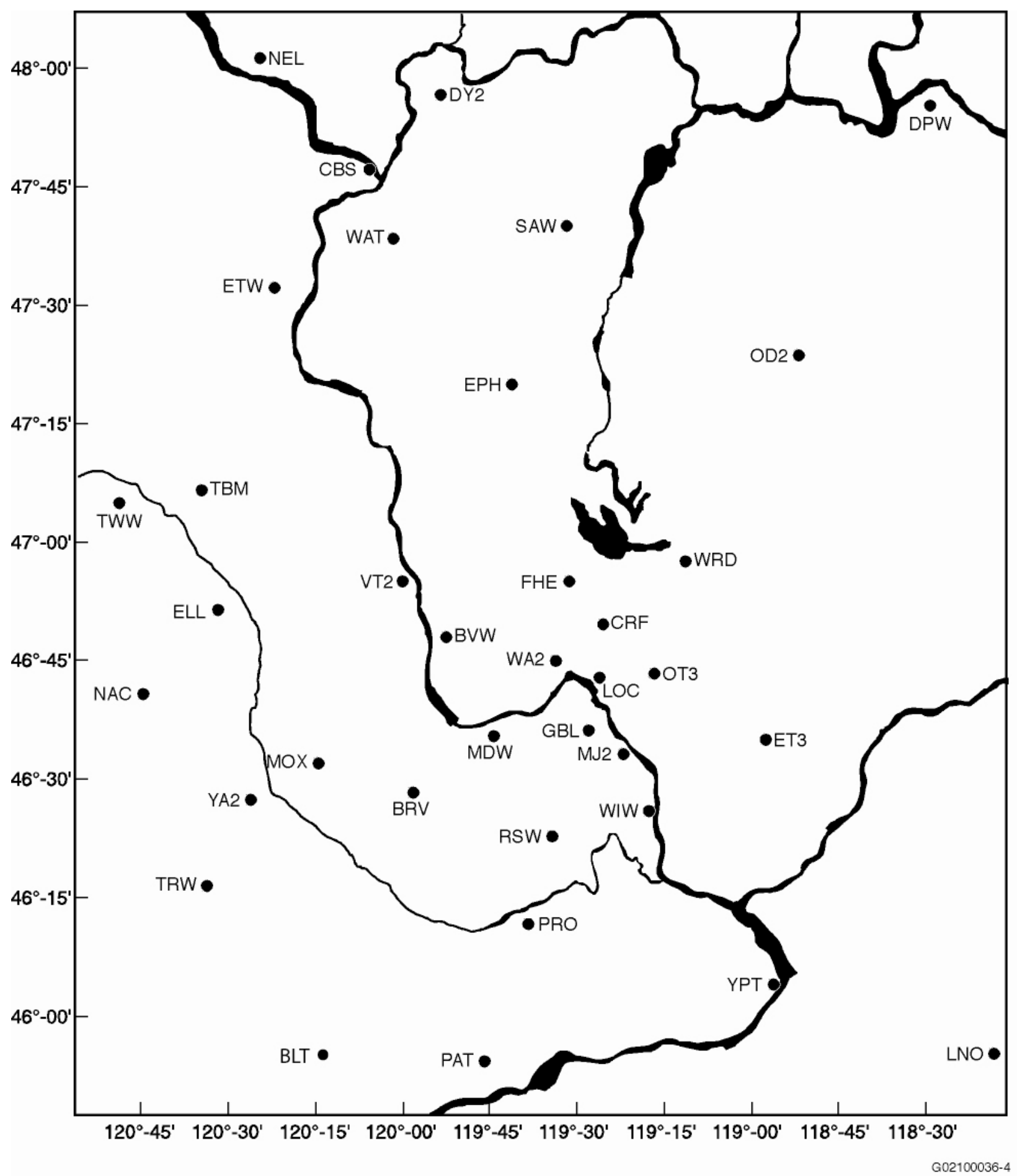

Figure 2.2. Locations of Seismograph Stations in the Eastern Washington Regional Network. (See Table 2.2 for location descriptions.) 


\subsubsection{Station Maintenance}

During the third quarter of FY 2007, the HSAP began upgrading the Hanford seismometer network with the ultimate goal of replacing analog radio telemetry with digital, web-based telemetry of the seismic traces to the Earthworm processing center located in Sigma V. This will help eliminate the reliance on archaic radio receiving and multiplexing equipment currently located in the Sigma V seismic processing laboratory. The first upgrade to the Hanford station will occur at the Gable Butte (GBB) station where tri-axial, broadband seismometers with built-in digitizing and telemetry equipment will be installed. A Quanterra Q330 data unit, a Packet Baler model PB14F and a Morningstar solar controller were purchased with installation underway and expected to be completed during the fourth quarter of FY 2007.

Progress was made in the effort to transfer three broadband seismometer sites (located at Black Rock, Eltopia, and Patterson) from the Incorporated Research Institutions for Seismology (IRIS) program currently operated by the National Science Foundation. Note that these IRIS stations will be shut down with stations sold to regional seismology programs at approximately one-third of the current procurement and installation price. We have visited several of the sites to communicate the transfer plans to the landowners. No problems with the transfer are envisioned. The tri-axial, broadband seismometer stations are completely digital and will represent an improvement to the Hanford network by being able to detect a broad range of seismic events.

\subsubsection{Data Acquisition}

The signals from the seismometer sites are monitored for changes in signal amplitude that are expected from earthquakes. The seismic network is subdivided into spatial groupings of stations that are monitored for nearly simultaneous amplitude changes, resulting in triggering a permanent recording of the events. The groupings and associated weighting schemes are designed to allow very small seismic events to be recorded and to minimize false triggers. Events are classified as local (south-central Washington near the Hanford Site), regional (Western U.S. and Canada), and teleseisms (from farther distances around the world). Local and regional events are usually earthquakes, but quarry and mining explosions are also recorded. Quarry and mining explosions can usually be identified from wave characteristics, time of day, and through confirmation with local government agencies and industries. Frequently, military exercises at the U.S. Army's Yakima Training Center produce a series of acoustic shocks that unavoidably trigger the recording system. Sonic booms and thunder also produce acoustic signals that trigger the recording system.

A PC-based system (Earthworm system) adapted from a USGS program and the UW system was implemented at Hanford during FY 1999. One system has been in continuous operation since January 6, 1999. A second, backup PC system was installed in mid-March 1999, and both systems have been running in parallel since that time. The hardware and software have been periodically upgraded. Data from triggers are collected on a SUN ${ }^{\text {TM }}$ (registered trademark of Sun Microsystems, Santa Clara, California) workstation that is used to determine earthquake locations and magnitudes (Section 3). Although the two systems are practically identical, there is enough granularity (signal-to-noise) in the trigger timing that they sometimes record exclusive events. In nearly all cases, these exclusive triggers are "false" triggers, not earthquakes or quarry blasts (i.e., from acoustic sources). The remainders are from barely detectable, small signals from regional and teleseismic earthquakes. 


\subsection{Strong Motion Accelerometer Sites}

\subsubsection{Location}

The Hanford SMA network consists of five free-field SMA sites (see Figure 2.1; Table 2.3). There is one free-field SMA located in each of the 200 Separations Areas, one adjacent to the K Basins in the 100-K Area, one adjacent to the 400 Area where the Fast Flux Test Reactor is located, and one at the south end of the 300 Area. With the termination of the Fast Flux Test Reactor and draining of the liquid sodium coolant having taken place, plans have been made to terminate this site and move the instrument to a new location.

Table 2.3. Free-Field Strong Motion Accelerometer Sites

\begin{tabular}{|c|c|c|c|}
\hline Site & Site ID & Location & $\begin{array}{c}\text { Latitude } \\
\text { Longitude } \\
\text { Elevation }\end{array}$ \\
\hline $100-\mathrm{K}$ Area & $\mathrm{H} 1 \mathrm{~K}$ & South of K Basins outside 100 Area fence lines. & $\begin{array}{l}46^{\circ} 38.51^{\prime} \\
119^{\circ} 35.53^{\prime} \\
152 \mathrm{~m}\end{array}$ \\
\hline 200 East Area & $\mathrm{H} 2 \mathrm{E}$ & $\begin{array}{l}\text { East of B Plant; northwest of Waste Treatment Plant; } \\
\text { north of } 7 \text { th Street and east of Baltimore Avenue. }\end{array}$ & $\begin{array}{l}46^{\circ} 33.58^{\prime} \\
119^{\circ} 32.00^{\prime} \\
210 \mathrm{~m}\end{array}$ \\
\hline 200 West Area & $\mathrm{H} 2 \mathrm{~W}$ & $\begin{array}{l}\text { West of Plutonium Finishing Plant (PFP) and 200-West } \\
\text { Area tree barrier. }\end{array}$ & $\begin{array}{l}46^{\circ} 33.11^{\prime} \\
119^{\circ} 38.64^{\circ} \\
201 \mathrm{~m}\end{array}$ \\
\hline 300 Area & $\mathrm{H} 3 \mathrm{~A}$ & $\begin{array}{l}\text { South end of } 300 \text { Area inside fence lines (NE 1/4, } \\
\text { SW 1/4, Sec. 11, T10N, R28E). }\end{array}$ & $\begin{array}{l}46^{\circ} 21.83^{\prime} \\
119^{\circ} 16.55^{\circ} \\
119 \mathrm{~m}\end{array}$ \\
\hline 400 Area & $\mathrm{H} 4 \mathrm{~A}$ & $\begin{array}{l}500 \mathrm{ft} \text { from fence line on east side of facility and north } \\
\text { of parking area). }\end{array}$ & $\begin{array}{l}46^{\circ} 26.13^{\prime} \\
119^{\circ} 21.30^{\prime} \\
171 \mathrm{~m}\end{array}$ \\
\hline
\end{tabular}

The instrumentation locations were chosen based on two criteria (Moore and Reidel 1996): 1) instruments should be located in areas having the highest densities of people and 2) instruments should be located in areas having hazardous facilities. Some of the highest concentrations of employees at Hanford are 200-East and West Areas, 100-K Area, the Fast Flux Test Facility (400 Area), and the 300 Areas. The 200 Areas are where high-level radioactive waste from past processing of fuel rods is stored in singleshell and double-shell tanks. In addition, the Canister Storage Facility that holds encapsulated spent fuel rods is in 200-East Area and the new Waste Treatment Plant is being constructed in 200-East Area. The 100-K Area contains the K Basins where spent fuel rods from the N Reactor are stored prior to encapsulation. The Cold Vacuum Drying Facility, located in the 100-K Area, is used to encapsulate spent fuel rods from the K Basins prior to shipment to the Canister Storage Building in 200-East Area.

\subsubsection{Site Design}

All free-field SMA sites consist of a four-panel solar array and two 30-gallon galvanized drums. Each panel has a maximum 42-watt output. The two 30-gallon drums are set in the ground such that the 
base of the drum is about $1 \mathrm{~m}$ below the surface. One drum houses only the SMA; the other drum, which is connected via a sealed conduit to the SMA drum, contains the batteries. Communication is through a General Packet Radio Service (GPRS) system, which provides a continuous radio data-link with an internet service provider. This GPRS system along with the solar power regulator is housed in a small enclosure mounted at the rear of the solar array. The enclosure serves as a junction box for all cabling between equipment inside and outside of the drums through conduit. The antenna for the GPRS is mounted on top of the enclosure. The enclosure permits quick access to check battery conditions and a connection directly to the RS-232 port of the SMA without removing the drum lids.

The SMA instruments are three-component units consisting of one vertical, one north-south horizontal, and one east-west horizontal data channel. The instruments in use are the ETNA ${ }^{\mathrm{TM}}$ system (registered trademark of Kinemetrics, Inc., Pasadena, California). Instrument specifications are summarized in Table 2.4. In addition to the three-component SMAs, each ETNA SMA unit contains a computer, and a Global Positioning System (GPS) receiver (Figure 2.3). These systems are housed in a watertight box.

The GPRS system provides the internet address connection to access the system. Stations can be monitored from any computer with appropriate access, and data can be downloaded to a dedicated computer in the Seismic Assessment laboratory. The data can also be downloaded directly at each site via a built in cable connection at the enclosure in case of communication failure.

Table 2.4. Instrument Parameters for the Kinemetrics ETNA ${ }^{\mathrm{TM}}$ System in the Hanford SMA Network

\begin{tabular}{|c|c|}
\hline Parameter & Value or Range \\
\hline \multicolumn{2}{|l|}{ Sensor } \\
\hline Type & Tri-Axial Episensor Accelerometer, orthogonally oriented \\
\hline Full-Scale & $\pm 2 g^{(a)}$ \\
\hline Frequency Range & $0-80 \mathrm{~Hz}$ \\
\hline Damping & Approximately $70 \%$ critical $^{(a)}$ \\
\hline \multicolumn{2}{|l|}{ Data Acquisition } \\
\hline Number of Channels & 3 \\
\hline Sample Rate & 18-bit resolution@ 200 samples/second \\
\hline Digital Output & Real-time, RS-232 Output Stream \\
\hline \multicolumn{2}{|l|}{ Seismic Trigger } \\
\hline Filter & $0.1-12.5 \mathrm{~Hz}$ \\
\hline Trigger level & $0.02 \% \mathrm{~g}^{(\mathrm{b})}$ \\
\hline Alarm (call-out) Threshold & Not activated \\
\hline Pre-Event Memory & $10 \mathrm{sec}$ \\
\hline Post-Event Time & $40 \mathrm{sec}$ \\
\hline \multicolumn{2}{|c|}{$\begin{array}{l}\text { (a) Setting is dependent on instrument calibration. } \\
\text { (b) See Section 2.2.4 for discussion of trigger thresholds. }\end{array}$} \\
\hline
\end{tabular}


Office of Seismic Assessment

Rm 2411, Sigma V Building

Richland, Washington

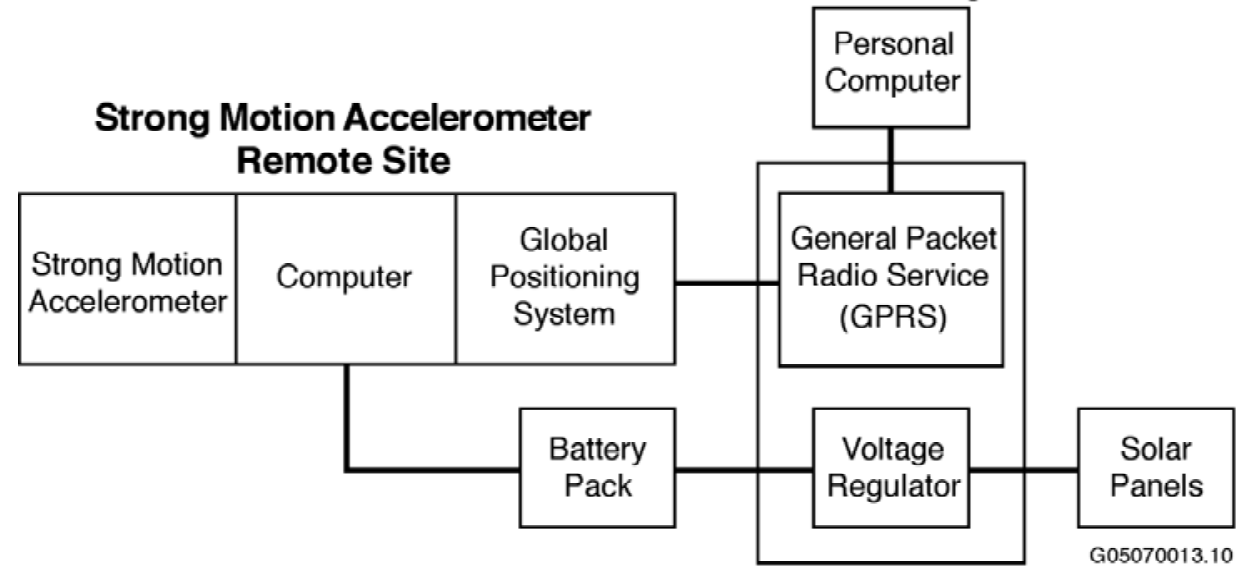

Figure 2.3. Schematic Diagram of a Strong Motion Accelerometer Installation

The SMAs have an internal GPS receiver used principally to link it to the National Bureau of Standards timing system. ${ }^{2}$ The GPS is internally activated approximately every 4 hours and checks the "location of the instrument" and the time. Any differences between the internal clock and the GPS time are recorded and saved by the SMA. Any corrections to the internal timing are made automatically. Typically, the greatest correction recorded is approximately 4 milliseconds.

\subsubsection{Strong Motion Accelerometer Operations Center}

The combined operations, data recording, data interpretation, and maintenance facility is located in the Sigma V Building and is operated by the Hanford Seismic Assessment Program (HSAP).

\subsubsection{Strong Motion Operational Characteristics}

The signals from the three accelerometer channels at each site are digitized with a 24-bit digitizer and temporarily stored in a memory buffer. The sampling rate of the digitizer is set to $200 \mathrm{samples} / \mathrm{second}$. The three channels are monitored for signals that equal or exceed a programmable trigger threshold. When one accelerometer channel is triggered, the other channels automatically record. The nominal threshold that was used from 1998 to 2006 was $0.05 \%$ of the full-scale range of $2.0 \mathrm{~g}$ ( $\mathrm{g}$ is the acceleration of gravity, $9.8 \mathrm{~m} / \mathrm{s}^{2}$ or $32 \mathrm{ft} / \mathrm{s}^{2}$ ) or $0.001 \mathrm{~g}$. Threshold trigger levels are adjusted to trigger infrequently on the noise sources (e.g., vehicles, sonic booms) near each site. In 2006, new SMA systems with larger storage allowed the trigger thresholds to be reduced to $0.01 \%$ full-scale or $0.0002 \mathrm{~g}$ (see Section 5). This provides ground motion data for smaller, non-damaging earthquakes that can be useful in estimating the ground motion expected from larger earthquakes, and to confirm correct operation of the instruments by analyzing the smaller-amplitude triggers. The recorders store information for 10 seconds before the trigger threshold is exceeded and for 40 seconds after the trigger threshold ceases to be exceeded.

\footnotetext{
${ }^{2}$ The GPS antenna is mounted on the enclosure at the rear of the solar array.
} 


\subsection{Earthquake Catalog Description}

Seismic Assessment Project staff uses an interactive program called XPED that was developed at the University of Washington to determine earthquake locations and magnitudes. This program operates on the sections of time saved in files by the trigger algorithm of the Earthworm system. It provides the user with the ability to measure the arrival times and durations of seismic waves from earthquakes and determine the locations and magnitudes of the events. Locations of teleseismic and regional earthquakes are interpreted and saved for operational and quality review and documentation, and are not reported here. Local earthquakes near the Hanford Site $\left(46^{\circ}-47^{\circ} \mathrm{N}\right.$ latitude, $119^{\circ}-120^{\circ} \mathrm{W}$ longitude) are reported in this report (Table 3.1). Other earthquakes in southeast Washington are kept on file.

\subsection{Coda Length Magnitude}

Coda-length magnitude $\left(\mathrm{M}_{\mathrm{c}}\right)$, an estimate of local magnitude $\left(\mathrm{M}_{\mathrm{L}}\right)$ (Richter 1958), is calculated using the coda-length/magnitude relationship determined for Washington State by Crosson (1972).

This relationship is:

$$
\mathrm{M}_{\mathrm{c}}=2.82 \log (\mathrm{D})-2.46 \text {, }
$$

where $\mathrm{D}$ is the duration of the observed signal. Many of the earthquakes have magnitude determinations that are very small, $M_{c}<0$, and highly uncertain; earthquakes smaller than $M_{c} 0.5$ will be described as "approximately $0 \mathrm{M}_{\mathrm{c}}$ " in Section 4 . Coda-length magnitudes for events classified as explosions are not reported because they are biased by a prominent surface wave that extends the apparent duration in a way inconsistent with coda-length measurement.

\subsection{Velocity Model}

The program XPED uses the velocities and layer depths given in Table 3.2. This model does not include a surficial layer for the Hanford formation or Ringold Formation sediments because most stations are located on basalt. Time corrections, which account for elevation, or local differences in the velocity model (i.e., stations on sedimentary layers), are determined empirically from sets of accurately-located earthquakes and explosions in the region.

\subsection{Quality Factors (Q)}

XPED assigns a two-letter Quality factor (Table 3.1) that indicates the general reliability of the solution (A is best quality, $\mathbf{D}$ is worst). Similar quality factors are used by the USGS for events located with the computer program HYPO71. The first letter of the quality code is a measure of the hypocenter quality based primarily on travel time residuals. For example: Quality A requires a root-mean-square residual (RMS) less than 0.15 seconds while a RMS of 0.5 seconds or more is $\mathbf{D}$ quality (other estimates of the location uncertainty also affect this quality parameter). The second letter of the quality code is related to the spatial distribution of stations that contribute to the event's location, including the number of stations (NS), the number of p-wave and s-wave phases (NP), the largest gap in event-station azimuth distribution (GAP), and the closest distance from the epicenter to a station (DMIN). Quality A requires a solution with NP $>8, \mathbf{G A P}<90^{\circ}$, and DMIN $<5 \mathrm{~km}$ (or the hypocenter depth if it is greater than $5 \mathrm{~km}$ ). If $\mathbf{N P} \leq 5$, GAP $>180^{\circ}$, or DMIN $>50 \mathrm{~km}$, the solution is assigned Quality $\mathbf{D}$. 
Table 3.1. Local Seismic Data, April 1, 2007 to June 30, 2007

\begin{tabular}{|c|c|c|c|c|c|c|c|c|c|c|c|c|c|}
\hline Event ID & Type & Date & Time & Latitude & Longitude & Depth & Mag & NS/NP & Gap & Dmin & RMS & Q & Location \\
\hline 07041401530 & & $07 / 04 / 14$ & 01:53:30.61 & 46N57.64 & 119W38.38 & 0.02 & 1.1 & $16 / 16$ & 136 & 10 & 0.11 & $\mathrm{AC}$ & $26 \mathrm{~km} \mathrm{E}$ of Vantage \\
\hline 07041620074 & & $07 / 04 / 16$ & $20: 08: 12.54$ & $46 \mathrm{~N} 24.09$ & 119W23.91 & 3.25 & 2.0 & $30 / 31$ & 55 & 1 & 0.14 & AA & $4 \mathrm{~km} \mathrm{SW}$ of 400 Area \\
\hline 07041721025 & $\mathrm{P}$ & $07 / 04 / 17$ & 21:03:12.31 & $46 \mathrm{~N} 57.17$ & 119W04.49 & 0.83 & & $22 / 22$ & 123 & 5 & 0.12 & $\mathrm{AB}$ & $16 \mathrm{~km}$ NNE of Othello \\
\hline 07042212055 & & $07 / 04 / 22$ & 12:06:21.05 & $46 \mathrm{~N} 23.92$ & 119W23.98 & 3.77 & 0.1 & $8 / 09$ & 126 & 1 & 0.03 & $\mathrm{AB}$ & $5 \mathrm{~km} \mathrm{SW}$ of 400 Area \\
\hline 07043005303 & & $07 / 04 / 30$ & 05:30:58.10 & $46 \mathrm{~N} 23.90$ & 119W23.79 & 4.22 & 0.5 & $9 / 09$ & 128 & 2 & 0.07 & $\mathrm{AB}$ & $5 \mathrm{~km} \mathrm{SW}$ of 400 Area \\
\hline 07050719172 & & $07 / 05 / 07$ & 19:17:50.48 & $46 \mathrm{~N} 18.52$ & 119W40.53 & 5.55 & 1.7 & $12 / 13$ & 164 & 10 & 0.08 & $\mathrm{AC}$ & $13 \mathrm{~km}$ NNE of Prosser \\
\hline 07050819191 & & $07 / 05 / 08$ & 19:19:36.46 & $46 \mathrm{~N} 54.51$ & 119W55.56 & 2.17 & 1.4 & $13 / 13$ & 121 & 8 & 0.10 & $\mathrm{AB}$ & $7 \mathrm{~km}$ SE of Vantage \\
\hline 07051000535 & & $07 / 05 / 10$ & $00: 54: 17.15$ & $46 \mathrm{~N} 22.83$ & 119W25.25 & 0.02 & -0.3 & $7 / 07$ & 125 & 1 & 0.11 & $\mathrm{AB}$ & $8 \mathrm{~km} \mathrm{SW}$ of 400 Area \\
\hline 07051522025 & $\mathrm{P}$ & $07 / 05 / 15$ & 22:03:04.44 & $46 \mathrm{~N} 26.11$ & 119W01.24 & 0.04 & & $8 / 08$ & 115 & 17 & 0.15 & $\mathrm{AC}$ & $22 \mathrm{~km} \mathrm{ENE}$ of 300 Area \\
\hline 07051800493 & $\mathrm{X}$ & $07 / 05 / 18$ & 00:50:01.21 & $46 \mathrm{~N} 27.78$ & 119W48.00 & 7.27 & & $6 / 06$ & 164 & 8 & 0.04 & $\mathrm{AC}$ & $16 \mathrm{~km} \mathrm{SW}$ of $200 \mathrm{West}$ \\
\hline 07051823301 & $\mathrm{X}$ & $07 / 05 / 18$ & $23: 30: 44.30$ & $46 \mathrm{~N} 26.89$ & 119W48.10 & 0.34 & & $6 / 06$ & 175 & 10 & 0.04 & $\mathrm{AC}$ & $18 \mathrm{~km} \mathrm{SW}$ of $200 \mathrm{West}$ \\
\hline 07051901022 & $\mathrm{X}$ & $07 / 05 / 19$ & 01:02:43.84 & $46 \mathrm{~N} 28.47$ & 119W47.42 & 12.31 & & $7 / 07$ & 154 & 7 & 0.11 & $\mathrm{BC}$ & $15 \mathrm{~km} \mathrm{SW}$ of $200 \mathrm{West}$ \\
\hline 07051902302 & $\mathrm{X}$ & $07 / 05 / 19$ & 02:30:44.28 & $46 \mathrm{~N} 26.86$ & 119W47.47 & 0.39 & & $6 / 06$ & 174 & 9 & 0.15 & $\mathrm{BC}$ & $17 \mathrm{~km} \mathrm{SW}$ of $200 \mathrm{West}$ \\
\hline 07051903414 & $\mathrm{X}$ & $07 / 05 / 19$ & 03:42:04.05 & $46 \mathrm{~N} 26.98$ & 119W48.11 & 0.53 & & $7 / 07$ & 174 & 10 & 0.06 & $\mathrm{AC}$ & $17 \mathrm{~km} \mathrm{SW}$ of 200 West \\
\hline 07052004151 & $\mathrm{X}$ & $07 / 05 / 20$ & $04: 15: 43.62$ & $46 \mathrm{~N} 27.19$ & 119W48.14 & 0.44 & & $10 / 10$ & 122 & 9 & 0.10 & $\mathrm{AB}$ & $17 \mathrm{~km} \mathrm{SW}$ of $200 \mathrm{West}$ \\
\hline 07052017451 & $\mathrm{X}$ & $07 / 05 / 20$ & $17: 45: 43.05$ & $46 \mathrm{~N} 26.93$ & 119W48.34 & 4.08 & & $7 / 07$ & 175 & 10 & 0.03 & $\mathrm{AC}$ & $18 \mathrm{~km} \mathrm{SW}$ of $200 \mathrm{West}$ \\
\hline 07052715202 & & $07 / 05 / 27$ & $15: 20: 45.05$ & $46 \mathrm{~N} 32.87$ & 119W44.58 & 20.08 & 1.4 & $20 / 20$ & 76 & 3 & 0.06 & $\mathrm{AA}$ & $8 \mathrm{~km} \mathrm{~W}$ of $200 \mathrm{West}$ \\
\hline 07052818365 & & $07 / 05 / 28$ & $18: 37: 22.00$ & $46 \mathrm{~N} 30.04$ & 119W41.55 & 9.21 & -0.8 & $5 / 07$ & 168 & 2 & 0.10 & $\mathrm{BD}$ & $8 \mathrm{~km} \mathrm{SSW}$ of $200 \mathrm{West}$ \\
\hline 07052819032 & & $07 / 05 / 28$ & 19:03:54.89 & $46 \mathrm{~N} 29.98$ & 119W40.78 & 8.77 & -0.4 & $7 / 07$ & 147 & 3 & 0.06 & $\mathrm{AC}$ & $7 \mathrm{~km} \mathrm{SSW}$ of $200 \mathrm{West}$ \\
\hline 07052819035 & & $07 / 05 / 28$ & 19:04:28.80 & $46 \mathrm{~N} 29.91$ & 119W41.24 & 8.98 & -0.2 & $6 / 07$ & 163 & 3 & 0.03 & $\mathrm{AC}$ & $8 \mathrm{~km} \mathrm{SSW}$ of $200 \mathrm{West}$ \\
\hline 07060213283 & & $07 / 06 / 02$ & 13:28:56.10 & $46 \mathrm{~N} 34.49$ & 119W41.06 & 19.56 & 0.3 & $8 / 08$ & 104 & 5 & 0.05 & $\mathrm{AB}$ & $4 \mathrm{~km} \mathrm{WNW}$ of $200 \mathrm{West}$ \\
\hline 07060923182 & & $07 / 06 / 09$ & $23: 18: 51.39$ & $46 \mathrm{~N} 23.90$ & 119W23.78 & 3.91 & -0.1 & $8 / 08$ & 128 & 2 & 0.07 & $\mathrm{AB}$ & $5 \mathrm{~km} \mathrm{SW}$ of 400 Area \\
\hline 07061413091 & & $07 / 06 / 14$ & 13:09:34.75 & $46 \mathrm{~N} 51.77$ & 119W36.37 & 17.11 & 0.8 & $28 / 32$ & 71 & 12 & 0.12 & $\mathrm{AA}$ & $25 \mathrm{~km} \mathrm{~N}$ of $100-\mathrm{K}$ \\
\hline 07061515121 & & $07 / 06 / 15$ & $15: 12: 40.20$ & $46 \mathrm{~N} 32.61$ & 119W43.64 & 17.53 & -0.1 & $11 / 12$ & 89 & 2 & 0.05 & AA & $7 \mathrm{~km} \mathrm{WSW}$ of $200 \mathrm{West}$ \\
\hline 07061517213 & & $07 / 06 / 15$ & $17: 21: 57.93$ & $46 \mathrm{~N} 32.68$ & 119W43.80 & 17.60 & 0.4 & $11 / 11$ & 96 & 3 & 0.04 & $\mathrm{AB}$ & $7 \mathrm{~km} \mathrm{WSW}$ of $200 \mathrm{West}$ \\
\hline 07061817434 & $\mathrm{P}$ & $07 / 06 / 18$ & $17: 44: 10.43$ & $46 \mathrm{~N} 16.10$ & 119W27.83 & 0.30 & & $7 / 07$ & 127 & 3 & 0.10 & $\mathrm{AB}$ & $13 \mathrm{~km} \mathrm{~W}$ of Richland \\
\hline
\end{tabular}




\section{Explanation of Table 3.1}

Event ID: The Earthworm Recording System creates the identification number. XPED uses the year, month, day, and time to create a unique number for each event.

Type: $\quad$ P is Probable Blast; X is Confirmed Blast; F is Felt Earthquake; blank is local earthquake.

Date: The year and day of the year in Universal Time Coordinated (UTC). UTC is used throughout this report unless otherwise indicated.

Time: The origin time of the earthquake given in UTC. To covert UTC to Pacific Standard Time, subtract eight hours; to Pacific Daylight Time, subtract seven hours.

Latitude: North latitude, in degrees and minutes, of the earthquake epicenter.

Longitude: West longitude, in degrees and minutes, of the earthquake epicenter.

Depth: $\quad$ The depth of the earthquake in kilometers $(\mathrm{km})$.

Mag: The magnitude is expressed as Coda-Length magnitude $\mathrm{M}_{\mathrm{c}}$, an estimate of local magnitude $\mathrm{M}_{\mathrm{L}}$ (Richter 1958). If magnitude is blank, a determination was not made.

NS/NP: $\quad$ Number of stations/number of phases used in the solutions.

Gap: Azimuthal gap. The largest angle (relative to the epicenter) containing no stations.

DMIN: The distance from the earthquake epicenter to the closest station

RMS: $\quad$ The root-mean-square residual (observed arrival times minus the predicted arrival times) at all stations used to locate the earthquake. It is only useful as a measure of quality of the solution when five or more well-distributed stations are used in the solution. Good solutions are normally characterized by RMS values of less than about 0.3 seconds.

Q: $\quad$ The Quality Factors indicate the general reliability of the solution/location (A is best quality, D is worst). See Section 3.3 of this report, "Quality Factors." 
Table 3.2. Seismic Velocities for Columbia Basin Stratigraphy (from Rohay et al. 1985)

\begin{tabular}{||c|l|c||}
\hline \hline $\begin{array}{c}\text { Depth to Top of Velocity } \\
\text { Layer }(\mathrm{km})\end{array}$ & \multicolumn{1}{|c|}{ Stratigraphy } & $\begin{array}{c}\text { Velocity } \\
(\mathrm{km} / \mathrm{sec})\end{array}$ \\
\hline \hline 0.0 & $\begin{array}{l}\text { Saddle Mountains and Wanapum Basalts and intercalated } \\
\text { Ellensburg Formation }\end{array}$ & 3.7 \\
\hline 0.4 & Grande Ronde Basalt and pre-basalt sediments & 5.2 \\
\hline 8.5 & Crystalline Basement, Layer 1 & 6.1 \\
\hline 13.0 & Crystalline Basement, Layer 2 & 6.4 \\
\hline 23.0 & Sub-basement & 7.1 \\
\hline 38.0 & Mantle & 7.9 \\
\hline
\end{tabular}




\subsection{Geology and Tectonic Analysis}

The Hanford Site lies within the Columbia Basin, which is an intermontane basin between the Cascade Range and the Rocky Mountains that is filled with Cenozoic volcanic rocks and sediments. This basin forms the northern part of the Columbia Plateau physiographic province (Fenneman 1931) and the Columbia River flood-basalt province (Reidel and Hooper 1989). In the central and western parts of the Columbia Basin, the Columbia River Basalt Group (CRBG) overlies Tertiary continental sedimentary rocks and is overlain by late Tertiary and Quaternary fluvial and glaciofluvial deposits (Campbell 1989; Reidel et al. 1989, 1994; DOE 1988). In the eastern part, a thin $(<100 \mathrm{~m})$ sedimentary unit separates the basalt and underling crystalline basement and a thin $(<10 \mathrm{~m})$ veneer of eolian sediments overlies the basalt (Reidel et al. 1989, 1994).

The Columbia Basin has two structural subdivisions or subprovinces: the Yakima Fold Belt and the Palouse Slope. The Yakima Fold Belt includes the western and central parts of the Columbia Basin and is a series of anticlinal ridges and synclinal valleys with major thrust faults typically along the northern flanks (Figure 4.1) (Reidel and Fecht 1994a, 1994b). The Palouse Slope is the eastern part of the basin and is less deformed than the Yakima Fold Belt with only a few faults and low amplitude, long wavelength folds on an otherwise gently westward dipping paleoslope. Figure 4.2 shows north-south (B-B') and east-west (A-A') cross sections through the Columbia Basin based on surface mapping (Reidel and Fecht 1994a, 1994b), deep boreholes (Reidel et al. 1994), geophysical data (Rohay et al. 1985; DOE 1988), and magnetotelluric data obtained as part of BWIP (DOE 1988).

\subsection{Earthquake Stratigraphy}

Studies of seismicity at the Hanford Site have shown that the seismic activity is related to crustal stratigraphy (large groupings of rock types) (Rohay et al. 1985; DOE 1988). The main geologic units important to earthquakes at the Hanford Site and the surrounding area are:

- The Miocene Columbia River Basalt Group (CRBG)

- Pre-basalt sediments of Paleocene, Eocene, Oligocene, and Early Miocene age

- The crystalline basement consisting of two layers composed of Precambrian and Paleozoic craton

- Mesozoic accreted terranes.

\subsection{Geologic Structure Beneath the Monitored Area}

Between the late 1950s and the mid 1980s, deep boreholes were drilled for hydrocarbon exploration in the Columbia Basin. These boreholes provided accurate measurements of the physical properties of the CRBG and the pre-basalt sediments (Reidel et al. 1989, 1994), but the thickness of the pre-basalt sediments and nature of the crystalline basement are still poorly understood. The difference between the thicknesses listed in Table 4.1 and the thicknesses of the crustal layers in the velocity model in Table 3.2 reflect data specific to UW's crustal velocity model for eastern Washington. Table 4.1 is derived from Reidel et al. (1994) and was developed for the geologic interpretation in this report. The thicknesses of these units are variable across the monitored area. Table 4.1 summarizes the approximate thickness at the borders of the monitored area. 


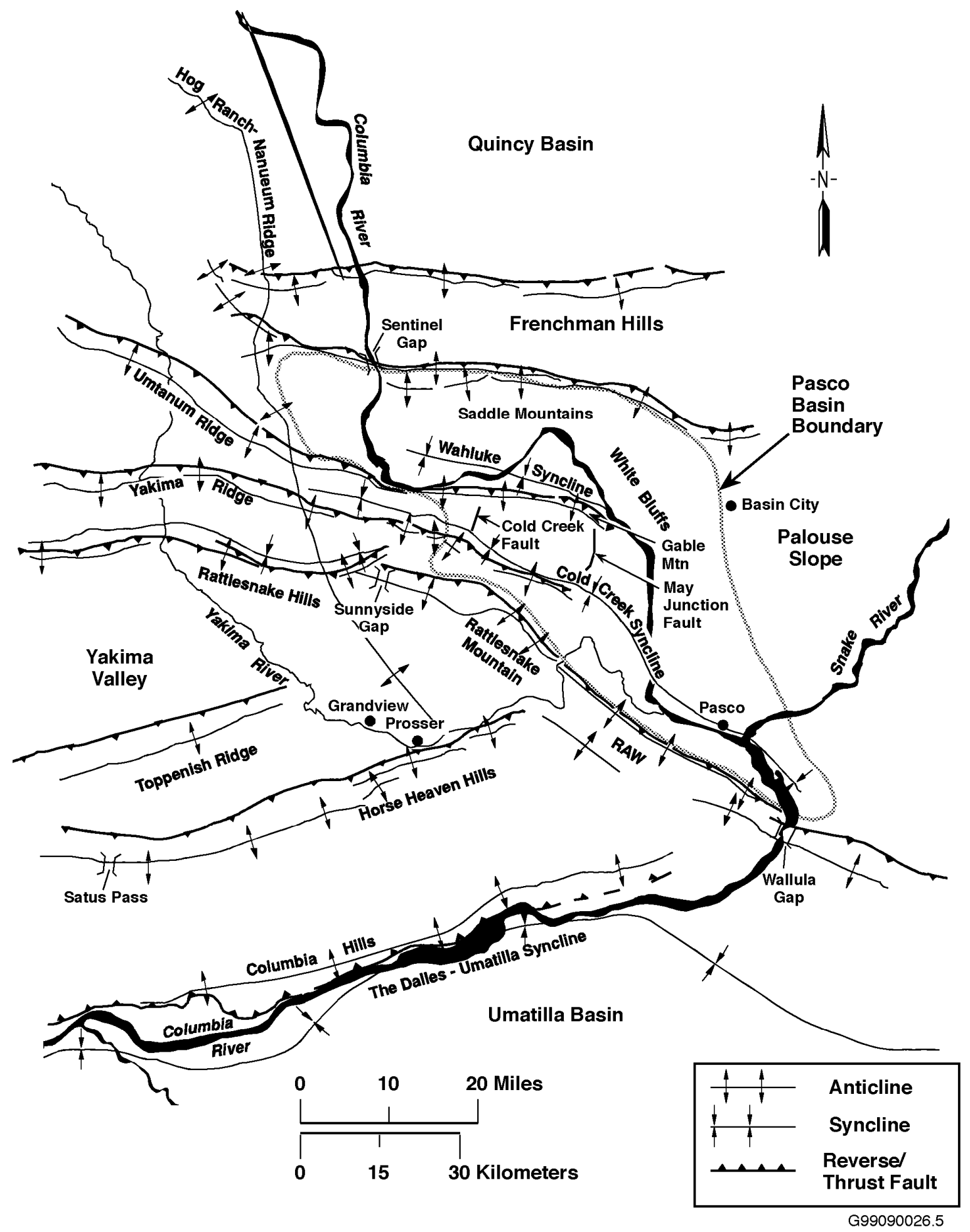

Figure 4.1. Tectonic Map of Columbia Basin Showing Major Seismic Source Structures 


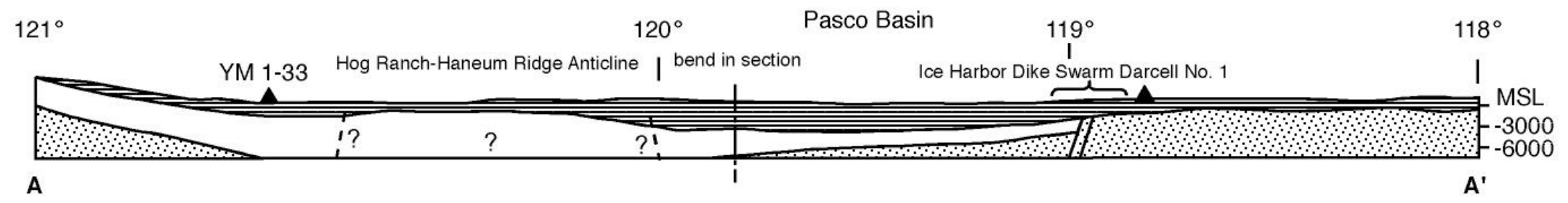

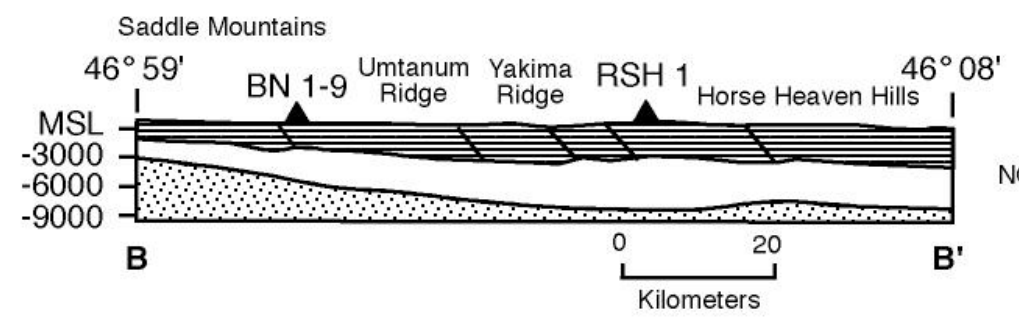

A Hydrocarbon exploration borehole
豆 Columbia River Basalt Group
NO VERTICAL EXAGgERATION

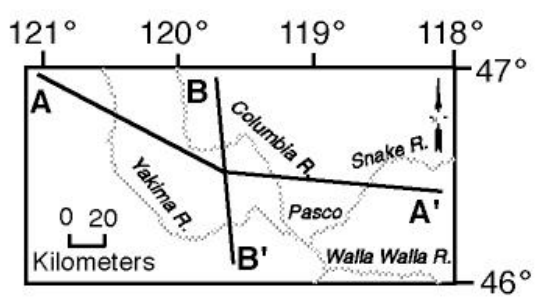

$\square$ Tertiary sediments

Basement rock

Figure 4.2. Geologic Cross Sections Through the Columbia Basin (Reidel et al. 1994) 
Table 4.1. Thicknesses of Stratigraphic Units in the Monitoring Area (from Reidel et al. 1994)

\begin{tabular}{||l|c|c|c|c||}
\hline \multicolumn{1}{|c|}{ Stratigraphy } & North & South & East & West \\
\hline \hline Columbia River Basalt Group (includes suprabasalt sediments) & $3.0 \mathrm{~km}$ & $4.5 \mathrm{~km}$ & $2.2 \mathrm{~km}$ & $4.2 \mathrm{~km}$ \\
\hline Pre-Basalt Sediments & $3.0 \mathrm{~km}$ & $>4.5 \mathrm{~km}$ & 0 & $>6.0 \mathrm{~km}$ \\
\hline
\end{tabular}

The thickness of the basalt and the pre-basalt sediments varies as a result of different tectonic environments. The western edge of the North American craton (late Precambrian/Paleozoic continental margin and Precambrian craton) is located in the eastern portion of the monitored area (Reidel et al. 1994). The stratigraphy on the craton consists of CRBG overlying crystalline basement; the crystalline basement is continental crustal rock that underlies much of the western North America. The stratigraphy west of the craton consists of 4 to $5 \mathrm{~km}$ of CRBG overlying up to $6 \mathrm{~km}$ of pre-basalt sediments. This in turn overlies accreted terranes of Mesozoic age. The area west of the craton was subsiding during the Eocene and Oligocene, accumulating great thickness of pre-CRBG sediments. Continued subsidence in this area during the Miocene resulted in thicker CRBG compared to that on the craton. Subsidence continues today but at a greatly reduced rate (Reidel et al. 1994).

\subsection{Tectonic Pattern}

Studies have concluded that earthquakes can occur in the following six different tectonic environments (earthquake sources) at the Hanford Site (Geomatrix 1996).

- Major Geologic Structures. Reverse/thrust faults in the CRBG associated with major anticlinal ridges such as Rattlesnake Mountain, Yakima Ridge, and Umtanum Ridge could produce some of the largest earthquakes.

- Secondary faults. These faults are typically smaller (1 to $20 \mathrm{~km}$ ) than the main reverse/thrust faults that occur along the major anticlinal ridges (up to $100 \mathrm{~km}$ ). Secondary faults can be segment boundaries (tear faults) and small faults of any orientation that formed along with the main structure.

- Swarm areas. Small geographic areas not known to contain any geologic structures produce clusters of events (swarms), usually in the CRBG in synclinal valleys. These clusters consist of a series of small shocks with no outstanding principal event. Swarms occur over a period of days or months and the events may number into the hundreds and then quit, only to start again at a later date. This differs from the sequence of foreshocks, mainshock, and trailing-off aftershocks that have the same epicenter or are associated with the same fault system. In the past, swarms were thought to occur only in the CRBG. Most swarm areas are in the basalt but swarm events also appear to occur in all geologic layers. However, typically a swarm event at a specific time is usually restricted to one layer. There are seven earthquake swarm areas that are recognized in the Hanford Seismic Network area but this list will be updated as new swarm areas develop. The Saddle Mountains, Wooded Island, Wahluke, Coyote Rapids, and Horse Heaven Hills swarm areas are typically active at one time or another during the year (Figure 4.3). The other earthquake swarm areas are active less frequently.

- The entire Columbia Basin. The entire basin, including the Hanford Site, could produce a "floating" earthquake. A floating earthquake is one that, for seismic design purposes, can happen 
anywhere in a tectonic province and is not associated with any known geologic structure. Seismic interpretation classifies it as a random event for purposes of seismic design and vibratory ground motion studies.

- Basement source structures. Studies (Geomatrix 1996) suggest that major earthquakes can originate in tectonic structures in the crystalline basement. Because little is known about geologic structures in the crystalline basement beneath the Hanford Site, earthquakes cannot be directly tied to a mapped fault. Earthquakes occurring in the crystalline basement without known sources are treated as random events.

- The Cascadia Subduction Zone. This source has been postulated to be capable of producing a magnitude 9 earthquake. Because this source is along the western boundary of Washington State and outside the HSN, the Cascadia Subduction Zone is not an earthquake source that is monitored at the Hanford Site, so subduction zone earthquakes are not reported here. Because any earthquake along the Cascadia Subduction zone can have a significant impact on the Hanford Site or can be felt like the February 2001 Nisqually earthquake, UW monitors and reports on this earthquake source for the DOE. Ground motion from any moderate or larger Cascadia Subduction Zone earthquake is detected by Hanford SMAs and reported (see Section 5.0).

\subsection{Depth of Earthquakes}

Since records have been kept, most of the earthquakes at the Hanford Site have originated in the CRBG layer. The crystalline basement has had the next greatest amount of earthquakes followed by the pre-basalt sediments. The stratigraphic units for local earthquakes recorded during FY 2007 are listed in Table 4.2.

Table 4.2. Number of Local Earthquakes Occurring in Stratigraphic Units

\begin{tabular}{||l|c|c|c|c|c||}
\hline \multicolumn{1}{|c|}{ Unit } & First Quarter & Second Quarter & Third Quarter & Fourth Quarter & FY 2007 \\
\hline \hline Basalt & 12 & 13 & 7 & - & 32 \\
\hline Pre-Basalt Sediments & 1 & 9 & 1 & - & 11 \\
\hline Crystalline Basement & 2 & 7 & 8 & - & 17 \\
\hline Total & 15 & 29 & 16 & - & 60 \\
\hline \hline
\end{tabular}

\subsection{Tectonic Activity}

\subsubsection{Summary}

During the third quarter FY 2007, twenty-six events were recorded within the Hanford Seismic Monitoring Network (Table 3.1; Figure 4.3). Of the twenty-six events, sixteen were determined to be earthquakes and ten events deemed to be blasts (Figure 4.3). Seven of these blasts were confirmed experimental explosions for a Laser Interferometric Gravitational-Wave Observatory (LIGO) noise study. The third quarter summary (Table 4.2 ) shows that seven events (44\%) occurred in the Columbia River Basalt Group; one event (6\%) occurred in the pre-basalt sediments; and eight events $(50 \%)$ occurred in the crystalline basement. 


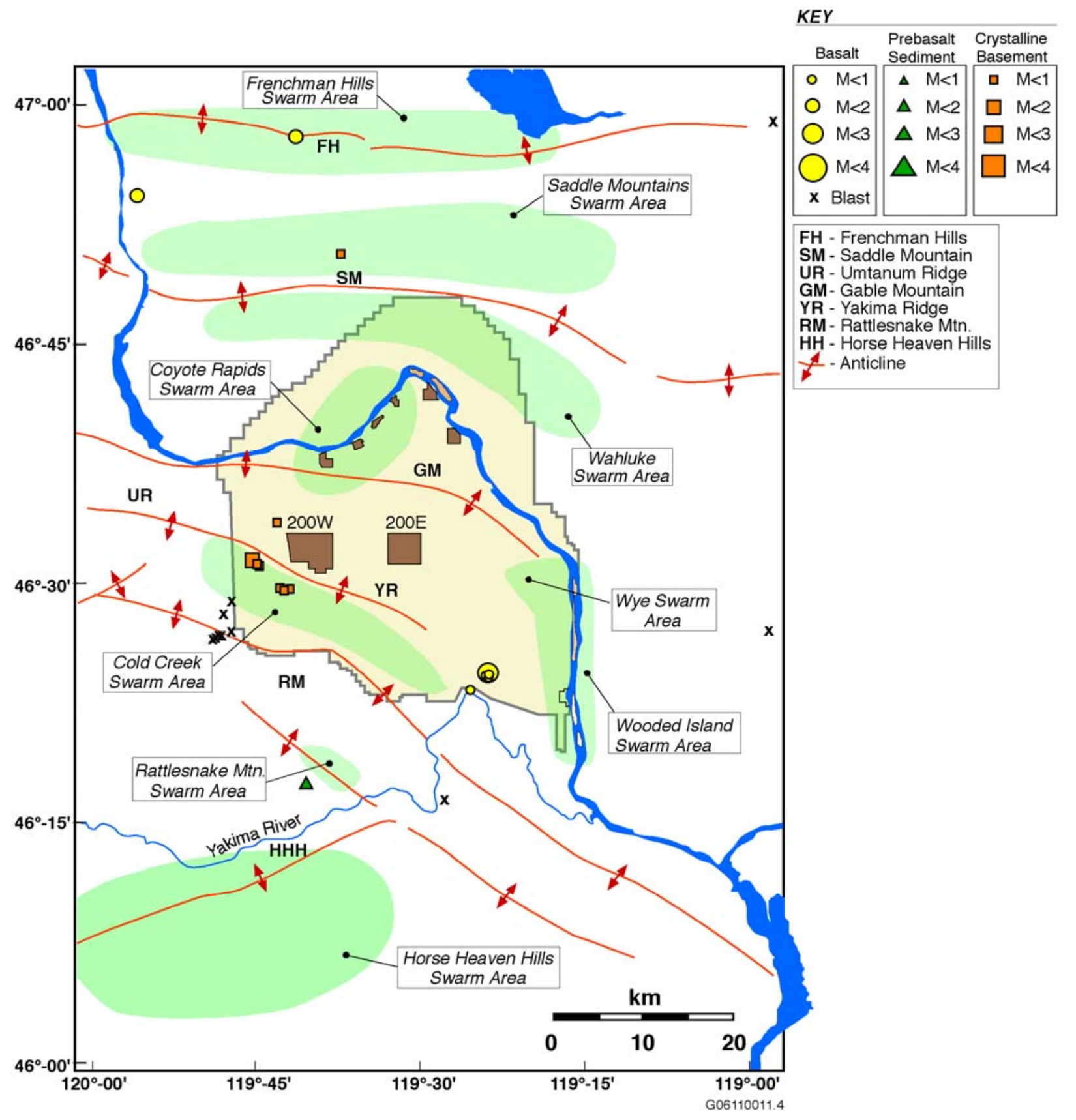

Figure 4.3. Location of all Earthquakes Occurring in the Hanford Monitoring Area Between April 1, 2007 and June 30, 2007 (Third Quarter)

Consulting Table 4.3, eight events (50\%) occurred as earthquake swarms, and eight events (50\%) were characterized as random events. 
Table 4.3. Summary of Earthquake Locations for FY 2007

\begin{tabular}{|c|c|c|c|c|c|c|}
\hline & Seismic Sources & $\begin{array}{l}\text { First Quarter } \\
10 / 01-12 / 31\end{array}$ & $\begin{array}{c}\text { Second Quarter } \\
1 / 01-3 / 31\end{array}$ & $\begin{array}{c}\text { Third Quarter } \\
4 / 01-6 / 30\end{array}$ & $\begin{array}{c}\text { Fourth Quarter } \\
7 / 01-9 / 30\end{array}$ & FY 2007 \\
\hline \multicolumn{2}{|c|}{ Geologic Structure } & 1 & - & - & - & 1 \\
\hline \multirow{10}{*}{$\begin{array}{l}\text { Swarm } \\
\text { Areas }\end{array}$} & Frenchman Hills & - & - & 1 & - & 1 \\
\hline & $\begin{array}{l}\text { Saddle Mountains/ } \\
\text { Royal Slope }\end{array}$ & 3 & 2 & 1 & - & 6 \\
\hline & Wahluke Slope & 3 & 7 & - & - & 10 \\
\hline & Coyote Rapids & 3 & - & - & - & 3 \\
\hline & Wye & - & 1 & - & - & 1 \\
\hline & Wooded Island & - & - & - & - & \\
\hline & Cold Creek & - & - & 6 & - & 6 \\
\hline & Rattlesnake Mt. & - & - & - & - & \\
\hline & Horse Heaven Hills & - & - & - & - & \\
\hline & Total for swarm areas & 9 & 10 & 8 & - & 27 \\
\hline \multicolumn{2}{|c|}{ Random Events } & 5 & 19 & 8 & - & 32 \\
\hline \multicolumn{2}{|c|}{ Total for all earthquakes } & 15 & 29 & 16 & - & 60 \\
\hline
\end{tabular}

\subsubsection{Third Quarter Earthquakes of FY 2007}

Sixteen earthquakes occurred in the Hanford area during the third quarter of FY 2007 (April 1, 2007 through June 30, 2007 [Figure 4.3]) (Table 4.3).

\subsubsection{Location and Depth of Earthquakes}

During the third quarter of FY 2007, eight events occurred in swarm areas and eight events were classified as random. As previously discussed, small geographic areas not know to contain any geologic structures produce clusters of events (swarms) usually in the CBRG in synclinal valleys. In the past, swarms were thought to occur only in the CBRG, however, we now believe swarm events may occur in lower geologic layers. Our subsequent discussion will show examples of swarm events in deeper units. An earthquake also can be classified as a random event if it occurs in the basalt but is not located near any known geologic structure.

\subsection{Major Anticlinal Ridges}

There were no earthquakes associated with the major structures of the area surrounding the Hanford Site for the third quarter of FY 2007.

\subsection{Earthquake Swarm Areas}

Eight earthquakes were characterized as swarm events (Figure 4.3). An earthquake is classified as a swarm event if it is located within one of the swarm areas, even if it is an isolated event. 


\section{Frenchman Hills Swarm Area}

One earthquake occurred on April 14, 2007 near the middle of the Frenchman Hills Swarm Area. It was shallow and registered a magnitude of $1.1 \mathrm{M}_{\mathrm{c}}$ (Figure 4.3).

\section{Saddle Mountains Swarm Area}

An earthquake occurred in the south-central portion of the Saddle Mountains Swarm Area during the third quarter of FY 2007 (June 14, 2007). This earthquake was focused in the crystalline basement with magnitudes less than $1.0 \mathrm{M}_{\mathrm{c}}$ (Figure 4.3).

\section{Cold Creek Swarm Area}

Six deep crystalline events occurred in the Cold Creek Swarm Area, five of which were less than $1.0 \mathrm{M}_{\mathrm{c}}$ (Figure 4.3). One event, occurring on May 27, 2007, had a magnitude of $1.4 \mathrm{M}_{\mathrm{c}}$ and a depth of approximately $20 \mathrm{~km}$. These events occurred in two clusters of three events each, west and southwest of the 200-West Area.

\subsection{Random or Floating Events}

During the third quarter of FY 2007, we interpret eight random events to have occurred in the monitoring area. Seismic events located in the pre-basalt sediments or the crystalline basement are typically classified as random events unless they are thought to represent multiple events within a layer such as the two clusters previously discussed in the Cold Creek Swarm area.

Most of these random events were below magnitude $1.0 \mathrm{M}_{\mathrm{c}}$ and will not be discussed. The largest recorded earthquake of the third quarter FY 2007 was detected as a random event on April 16, 2007. It was magnitude $2.0 \mathrm{M}_{\mathrm{c}}$ and located $4 \mathrm{~km}$ southwest of the 400 Area. The depth of the event was approximately $3.3 \mathrm{~km}$ in the Columbia River Basalt Group. A pre-basalt earthquake occurred on May 7, 2007, at a depth of $5.5 \mathrm{~km}$. This event had a magnitude of $1.7 \mathrm{M}_{\mathrm{c}}$ and was located southwest of the Hanford boundary on the southwest flank of Rattlesnake Mountain. The remaining earthquake exceeding $1.0 \mathrm{M}_{\mathrm{c}}$ occurred on May 8, 2007, approximately $7 \mathrm{~km}$ southeast of Vantage, Washington. This event was in basalt, had a magnitude of $1.4 \mathrm{M}_{\mathrm{c}}$, and a depth of approximately $2.2 \mathrm{~km}$ (Figure 4.3 ). 


\subsection{Strong Motion Accelerometer Operations}

The Hanford SMA network has been in continuous operation since November 20, 1998. Initially, the threshold used in the SMA network was $0.001 \mathrm{~g}$ in order to provide ground motion for smaller, nondamaging earthquakes that can be useful in estimating the ground motion expected from larger earthquakes, and to confirm correct operation of the instruments by analyzing the smaller-amplitude triggers (see Section 2.2). In 2006, the trigger threshold was reduced to $0.0002 \mathrm{~g}$ when new instruments with greater storage capacity were installed, allowing more noise triggers to be saved without exceeding disk capacity.

\subsection{FY 2007 Triggers of the Hanford SMA Network}

The Hanford SMA network was triggered by the $2.0 \mathrm{M}_{\mathrm{c}}$ seismic event that occurred on April 16, 2007. That event was recorded on the 300 Area and the 400 Area SMA. Data shown in Figures 5.1 and 5.2 were plotted from event files downloaded from the SMA units.

Figure 5.1 shows the time history of ground acceleration recorded at the 300 Area SMA station. Converting the voltages shown in Figure 5.1 to ground acceleration, the maximum vertical acceleration was $0.07 \% \mathrm{~g}$ and the maximum horizontal acceleration was $0.05 \% \mathrm{~g}$. At the 400 Area SMA station, shown in Figure 5.2, the maximum vertical acceleration was $0.25 \% \mathrm{~g}$ and the maximum horizontal acceleration was $0.23 \% \mathrm{~g}$. Accelerations at the 400 Area SMA (5.2 km distant from the event) are 3 to 5 times larger than at the 300 Area SMA (13.5 km from the event). These are the first recordings of a small local earthquake on the SMA network. Previous earthquake triggers on the SMA network were from the February 28, 2001 magnitude 6.8 Nisqually earthquake in western Washington, and from the November 3, 2002 magnitude 7.9 Denali earthquake in Alaska. The upgrade of the SMA units last year provides for reduced trigger levels $(0.02 \%$ g compared to $0.10 \%$ to $0.20 \%$ g previously) that allowed the 300 Area SMA to trigger; the 400 Area SMA would have triggered at the higher $g$ threshold at this closer location. The reportable action level of $2 \% \mathrm{~g}$ for Hanford facilities is approximately 8 times larger than the peak accelerations observed at the 400 Area and no action was required. However, this earthquake did do damage to the vibration-sensitive optical systems at LIGO. 


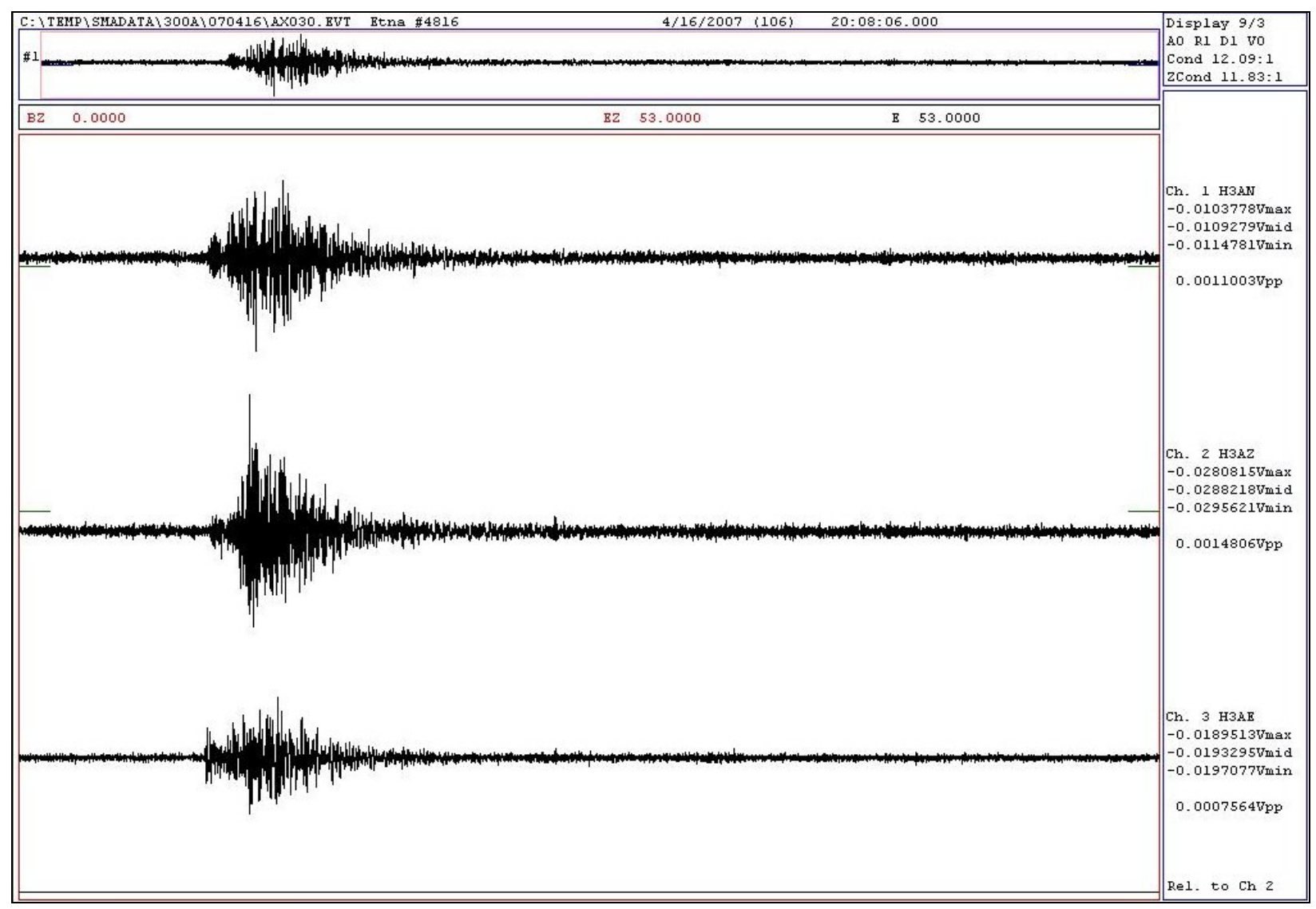

Figure 5.1. April 16, 2007 Microearthquake Acceleration Time Histories at 300 Area SMA 


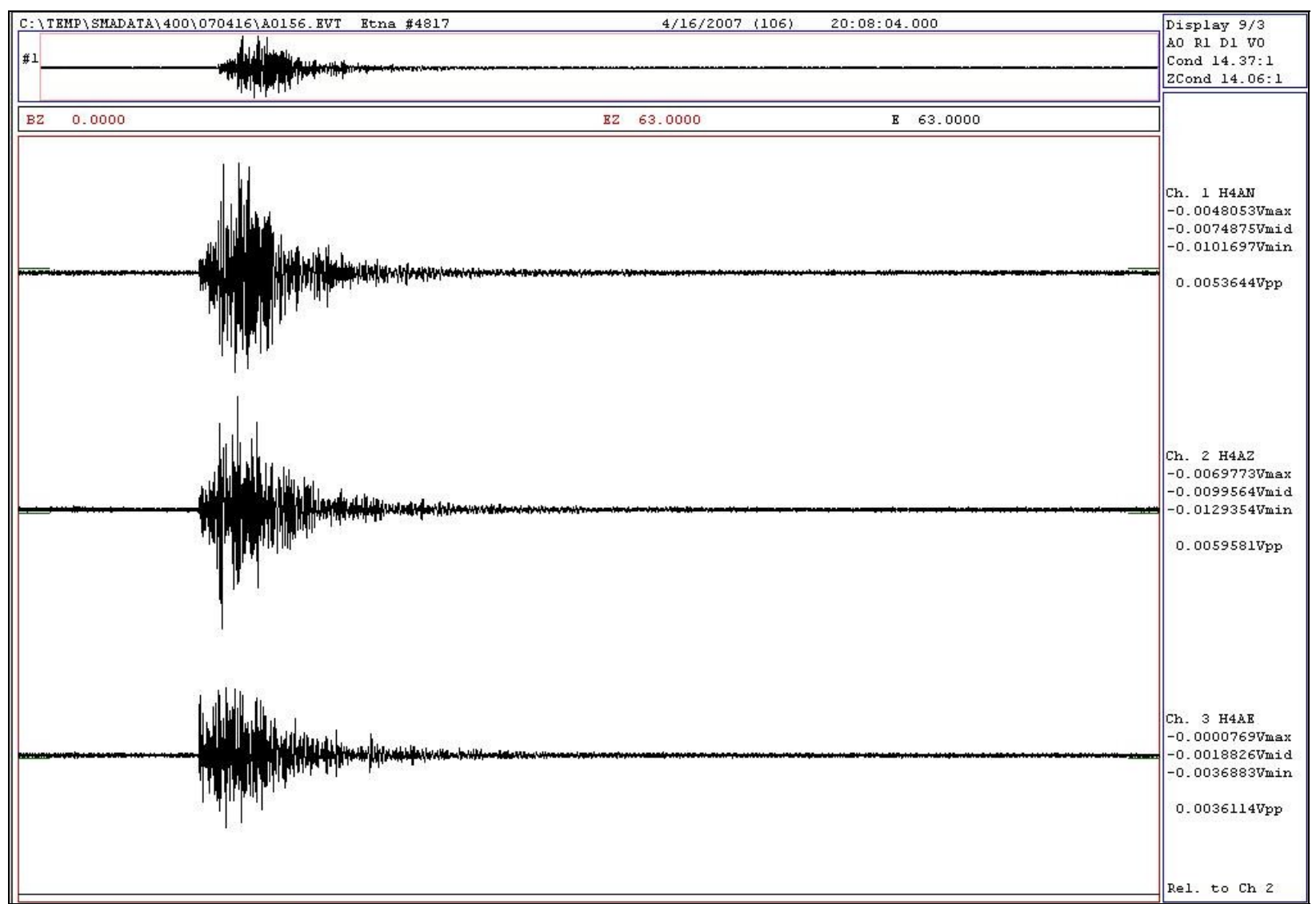

Figure 5.2. April 16, 2007 Microearthquake Acceleration Time Histories at 400 Area SMA 


\subsection{Capabilities in the Event of a Significant Earthquake}

The SMA network was designed to provide ground motion data in areas at the Hanford Site that have high densities of people and/or facilities containing hazardous materials in order to insure the Hanford Site is in compliance with DOE Order 420.1A, "Facility Safety." The network also allows the HSAP to support Hanford Site emergency services organizations in complying with DOE Order G 420.1-1, Section 4.7, "Emergency Preparedness and Emergency Communications," by providing area ground motion data in the event of an earthquake on the Hanford Site. This section summarizes the capabilities of the HSAP in the event of an earthquake at Hanford.

\subsection{Use of the SMA Network in the Event of an Earthquake}

Historically, only a few facilities at the Hanford Site had instruments to provide data on peak ground accelerations or any type of ground motion. The present SMA instruments were located so that if an earthquake occurred, ground motion data would be readily available to assess the damage at the 100-K Area, the 200-East and West Areas, and the 300 and 400 Area facilities, which have the greatest concentration of people and also contain hazardous materials (Moore and Reidel 1996).

Many facilities at the Hanford Site have undergone various degrees of seismic analysis either during design or during re-qualification. Although the seismic design of a building may be known, when an earthquake is "felt" in a facility on the Hanford Site, a determination must be made as to the extent of damage before it can be re-occupied and the systems restarted. A "felt" earthquake may not cause any significant damage to a building but, without adequate characterization of the ground motion, initial determination of the building's possibility of having damage may be impossible.

In the event of an earthquake such as the 2001 Nisqually earthquake, building managers, emergency directors, and engineers can obtain ground motion data recorded by the SMA network from the HSAP in the Sigma V Building. This is done through the Hanford Site Emergency Services Organization. Normal hours of operation for the HSAP are between 6 a.m. and 4:30 p.m., Monday through Friday. If a SMA is triggered, the HSAP will download events that were recorded and determine the peak ground accelerations. This information is then passed on to Hanford Emergency Services personnel where the facility engineers can use the data to determine if the ground motion exceeded, is equal to, or is less than the building design. This, along with assessments from trained engineers, allows the facility manager to make a rapid and cost-effective determination on whether a building is safe to re-occupy or should not be used until it has been inspected in more detail. Buildings that have designs exceeding the recorded ground motion could be put back into service very quickly; buildings with designs that are very close to or less than measured ground motion could be given priority for onsite damage inspections. 


\subsection{References}

Campbell NP. 1989. "Structural and Stratigraphic Interpretation of Rocks under the Yakima Fold Belt, Columbia Basin, Based on Recent Surface Mapping and Well Data." In SP Reidel and PR Hooper (eds.), Volcanism and Tectonism in the Columbia River Flood-Basalt Province Geological Society of America Special Paper 239, pp. 209-222.

Crosson RS. 1972. Small Earthquakes, Structure and Tectonics of the Puget Sound Region. Bulletin of the Seismological Society of America 62(5):1133-1171.

DOE. 1988. Site Characterization Plan for the Reference Location, Hanford, Washington-Consultation Draft. Report DOE/RW-0164, Vol. 1, U.S. Department of Energy, Washington, D.C.

DOE Order 420.1B, Chapter IV, Section 3.d. "Seismic Detection."

DOE Order G 420.1-1, Section 4.7. “Emergency Preparedness and Emergency Communications.”

Fenneman NM. 1931. Physiography of Western United States. McGraw-Hill, 534 p.

Geomatrix. 1996. Probabilistic Seismic Hazard Analysis, DOE Hanford Site, Washington. WHC-SDW236A-TI-002, Rev. 1, Westinghouse Hanford Company, Richland, Washington.

Moore C and SP Reidel. 1996. Hanford Site Seismic Monitoring Instrumentation Plan. WHC-SD-GNER-30036, Westinghouse Hanford Company, Richland, Washington.

Reidel SP and KR Fecht. 1994a. Geologic Map of the Richland 1:100,000 Quadrangle, Washington. Washington Division of Geology and Earth Resources Open File Report 94-8, 21 p., 1 plate.

Reidel SP and KR Fecht. 1994b. Geologic Map of the Priest Rapids 1:100,000 Quadrangle, Washington. Washington Division of Geology and Earth Resources Open File Report 94-13, 22 p., 1 plate.

Reidel SP and PR Hooper (eds.). 1989. Volcanism and Tectonism in the Columbia River Flood-Basalt Province Geological Society of America Special Paper 239, 386 p.

Reidel SP, NP Campbell, KR Fecht, and KA Lindsey. 1994. "Late Cenozoic Structure and Stratigraphy of South-Central Washington." In E Cheney and R Lasmanis (eds.), Regional Geology of Washington State, Washington Division of Geology and Earth Resources Bulletin 80, pp. 159-180, Olympia, Washington.

Reidel SP, KR Fecht, MC Hagood, and TL Tolan. 1989. "Geologic Development of the Central Columbia Plateau." In SP Reidel and PR Hooper (eds.), Volcanism and Tectonism in the Columbia River Flood-Basalt Province Geological Society of America Special Paper 239, pp. 247-264.

Richter CF. 1958. Elementary Seismology, W. H. Freeman and Company, p. 768. 
Rohay AC, DW Glover, and SD Malone. 1985. Time-Term Analysis of Upper Crustal Structure in the Columbia Basin, Washington. RHO-BW-SA-435 P, Rockwell Hanford Operations, Richland, Washington. 


\section{Distribution}

No. of

\section{Copies}

\section{OFFSITE}

Administrator

Kennewick General Hospital

P.O. Box 6128

Kennewick, WA 99336

Dr. R. Carson

Department of Geology

Whitman College

345 Bayer Avenue

Walla Walla, WA 99362

T. Conrads

Parsons Constructors, Inc.

3005 E. Ainsworth Street

Pasco, WA 99301

G. Crawford

Earthquake Program Manager

Washington Emergency Management Division

Building 20, M/S: TA-20

Camp Murray, WA 98430-5122

Idaho Geological Survey

Morrill Hall

University of Idaho

P.O. Box 443014

Moscow, ID 83844-3014

J. Kimball

NNSA NA 2.1

19901 Germantown Road

Germantown, MD 20874
No. of

Copies

S. Lilligren

Nez Perce Tribe

P.O. Box 365

Lapwai, ID 83540

J. Litehiser

Bechtel National, Inc.

P.O. Box 193965

San Francisco, CA 94119-3965

2 Oregon Department of Geology and Mineral Industries

Suite 965, 800 NE Oregon Street \#28

Portland, OR 97232

ATTN: Library

I. Madin

N. Rasmussen

3140 Ravenshoe Drive

Las Vegas, NV 89134

S. P. Reidel

WSU Tri-Cities

2710 University Drive

Richland, WA 99354

P. Rizzo

105 Mall Boulevard

Monroeville, PA 15146

M. Stickney

Montana Tech University

Earthquake Studies Office

Butte, MT 59701

A. Tallman

1940 Quail Court

West Richland, WA 99353 
No. of

Copies

5 University of Washington

Geophysics Program

P.O. Box 351650

Seattle, WA 98195-1650

ATTN: P. Bodin

R. Ludwin

S. Malone

R. Steele

J. Vidale

2 University of Washington

U.S. Geological Survey

P.O. Box 351650

Seattle, WA 98195

ATTN: C. Weaver

T. Yelin

U.S. Fish and Wildlife Service

3250 Port of Benton Boulevard

Richland, WA 99352

U.S. Geological Survey

Mail Stop 977

345 Middlefield Road

Menlo Park, CA 94025

ATTN: T. Brocher

2 Washington Division of Geology and Earth

Resources

P.O. Box 47007

Olympia, WA 98504-7007

ATTN: Library

T. Walsh

Washington State University

Department of Geology

P.O. Box 643420

Pullman, WA 99164-2812

R. Whale

Shell E\&P

200 N. Dairy Ashford

Houston, TX 77079
No. of

Copies

I. G. Wong

URS Corporation

1333 Broadway, Suite 800

Oakland, CA 94612

J. Zollweg

Boise State University

Department of Geosciences

Boise, ID 83725

\section{ONSITE}

7 DOE Richland Operations Office

B. L. Charboneau

A6-33

K. L. Flynn

A6-35

T. Y. Hale

A7-90

R. D. Hildebrand

A6-38

M. R. Moreno

H6-60

J. G. Morse

A6-38

Y. T. Sherman

A6-35

DOE Office of River Protection

L. F. Miller

H6-60

Bechtel Hanford, Inc.

K. R. Fecht

H9-01

5 CH2M HILL Hanford Group, Inc.

F. J. Anderson

H6-03

D. D. Bachland

S5-15

J. R. Freeman-Pollard

R3-77

D. T. Heimberger

S5-25

F. M. Mann

H6-03

\section{Duratek Federal Services Hanford}

R. T. Wilde

H8-44 
No. of

Copies

10 Fluor Hanford, Inc.

M. E. Brown

D. A. Conners

J. T. Curtis

S. A. Fargo

S. M. Faulk

B. H. Ford

D. G. Horton

T. P. Morales

M. I. Wood

M. T. York

Stoller

R. McCain
No. of

Copies

Washington State Department of Ecology

G5-51

T3-28

B3-15

H8-60

A3-05

E6-35

E6-35

A3-05

H8-44

N2-02

J. Caggiano

$\mathrm{H} 0-57$

14 Pacific Northwest National Laboratory

R. E. Clayton

K6-75

J. L. Devary

K6-96

D. C. Hartshorn

K6-75

P. E. Moore

J2-09

B. E. Opitz

K6-75

A. C. Rohay

K6-75

H. T. Schaef

K6-81

M. D. Sweeney (5)

K6-75

Hanford Technical Library (2)

B2-62 